Article

\title{
Techno-Economic Analysis (TEA) of Different Pretreatment and Product Separation Technologies for Cellulosic Butanol Production from Oil Palm Frond
}

\author{
Nazira Mahmud ${ }^{1,2}$ and Kurt A. Rosentrater $1, *$ (D) \\ 1 Department of Agricultural and Biosystems Engineering, Iowa State University, Elings Hall, Ames, IA 50011, \\ USA; nazira@ump.edu.my or nazira@iastate.edu \\ 2 Faculty of Industrial Sciences and Technology, University Malaysia Pahang, Lebuhraya Tun Razak, \\ Kuantan 26300, Malaysia \\ * Correspondence: karosent@iastate.edu; Tel.: +1-515-294-4019
}

Received: 27 November 2019; Accepted: 27 December 2019; Published: 1 January 2020

\begin{abstract}
Among the driving factors for the high production cost of cellulosic butanol lies the pretreatment and product separation sections, which often demand high amounts of energy, chemicals, and water. In this study, techno-economic analysis of several pretreatments and product separation technologies were conducted and compared. Among the pretreatment technologies evaluated, low-moisture anhydrous ammonia (LMAA) pretreatment has shown notable potential with a pretreatment cost of $\$ 0.16 / \mathrm{L}$ butanol. Other pretreatment technologies evaluated were autohydrolysis, soaking in aqueous ammonia (SAA), and soaking in sodium hydroxide solution $(\mathrm{NaOH})$ with pretreatment costs of $\$ 1.98 / \mathrm{L}, \$ 3.77 / \mathrm{L}$, and $\$ 0.61 / \mathrm{L}$, respectively. Evaluation of different product separation technologies for acetone-butanol-ethanol (ABE) fermentation process have shown that in situ stripping has the lowest separation cost, which was $\$ 0.21 / \mathrm{L}$. Other product separation technologies tested were dual extraction, adsorption, and membrane pervaporation, with the separation costs of $\$ 0.38 / \mathrm{L}, \$ 2.25 / \mathrm{L}$, and $\$ 0.45 / \mathrm{L}$, respectively. The evaluations have shown that production of cellulosic butanol using combined LMAA pretreatment and in situ stripping or with dual extraction recorded among the lowest butanol production cost. However, dual extraction model has a total solvent productivity of approximately $6 \%$ higher than those of in situ stripping model.
\end{abstract}

Keywords: ABE fermentation; LMAA pretreatment; techno-economic analysis; cellulosic butanol

\section{Introduction}

The potential of large-scale cellulosic butanol production is limited by the low efficiency of the pretreatment process as well as the extensive downstream processing requirement. Studies have revealed both operations as potentially driving the production cost of cellulosic butanol [1-4]. Pretreatment is essential to reduce the recalcitrant structure of lignocellulosic materials and therefore results in better sugar yield after the enzyme hydrolysis process [5]. Nevertheless, the process often requires harsh processing conditions (high temperature and pressure) as well as a high amount of chemical and water [6], which makes it unfeasible for commercial application.

Similarly, downstream processing in biobutanol production also entails considerable cost because of low productivity of the fermentation process (acetone-butanol-ethanol (ABE) fermentation) due to the toxic and inhibition effect given by the fermentation products to the microorganisms used. The known approach, capable of solving this problem, is to use the inline separation method which reduces the product concentration in the fermentation broth through the external loop (also called slipstream) of cell separation and recycling throughout the fermentation $[7,8]$. A more efficient approach is the in 
situ product separation process, which enables the product to be separated and removed from the fermentation system as soon as it is produced, avoiding microorganism inhibition.

Inline and in situ product separation methods have successfully increased ABE production from the concentration of $<2 \mathrm{wt} . \%$ to $46 \mathrm{wt}$.\% [9]. Several potential product separation approaches employing different principles including membrane-based, gas-liquid equilibrium, and liquid-liquid equilibrium are investigated in this study, which includes integrated fermentation-membrane pervaporation, integrated fermentation-adsorption technology, extractive fermentation, and integrated fermentation-in situ gas stripping [10]. Among the appealing characteristics of these approaches is the low energy requirement associated with the process through the application of mild reaction conditions compared to the conventional separation method (distillation), which is a crucial consideration when designing an industrial-scale separation process.

Various pretreatment and product separation approaches were developed to solve the problem. Researchers have been highlighting the issue of the current technologies and discussing the potential manipulation that could be conducted in terms of design, technical, and process parameters to achieve optimum separation from the selected process. For example, reducing total liquid requirement in a pretreatment process, controlling bubble size in the gas stripping process, searching for novel extractant and design improvement using membrane for solvent extraction process, development of stable adsorbent for adsorption process, and substitution of sweep gas by low vapor pressure for pervaporation process, as well as better preconditioning step prior to each mentioned technology $[5,7,8,11-14]$ have all been considered.

For commercial application, optimum performance must not be attenuated by adverse economic features. Other than capital cost, operating cost that involves mainly the energy cost is an important cost factor of a process. Previous work has revealed that conducting a separation at a higher temperature would likely increase its rate; however, it will also likely increase the cost of operation and harm the cell for an in situ separation approach [4]. Other expenditures such as purchasing the extractant, adsorbent, solvent, or other required chemical are similarly crucial in choosing a process for a commercial application. It is related to the loss that might be incurred, which will require many years for a production plant to break even. Hence, techno-economic analysis (TEA) of these processes is an essential key factor in determining the best method.

Between steam explosion, dilute sulfuric acid, ammonia fiber explosion (AFEX), and biological pretreatment, Baral \& Shah [15] concluded that steam explosion and dilute sulfuric acid pretreatment require the least cost mainly because of the high productivity of the process at low capital and energy requirement. AFEX pretreatment, although recording higher productivity, also required higher energy, therefore has a higher cost. It indicates that other than having a high amount of exposed carbohydrate after the pretreatment, the total energy required for the process was equally important. Also, a high capital process would only be feasible if the yield is high enough to compensate for the cost. This study focused on low-moisture anhydrous ammonia (LMAA) pretreatment, a process with potentially low energy, chemical, and liquid requirement, as well as production of no inhibitory compounds [16,17]. Several other pretreatments including alkali pretreatment were chosen to serve as a comparison for LMAA pretreatment.

Díaz \& Tost [18] has compared the extraction-based product separation method for biobutanol production. They found that extractive fermentation had significantly lower production cost than those of separate extraction systems, primarily due to the extensive requirement of high-pressure steam in the external extraction. Nevertheless, to model extractive fermentation is a challenge due to the complexity of the reaction. Therefore, work on the separate extraction approach is continued using various novel solvents in varying set-ups and the application of an on-site steam-generation system which would likely reduce the economic effect of high steam cost. For the adsorption process, Qureshi et al. [19] concluded that silicalite adsorbent possesses significant attraction over activated carbon (AC) adsorbent due to complete desorption of the products. Further study by Abdehagh et al. [20] concluded the contrary, where AC adsorbent was better than silicalite in terms of adsorption rate, 
adsorption capacity, and selectivity towards butanol. Their subsequent study confirmed that AC F-400 could achieve between $80-90 \%$ butanol desorption [21].

Recent studies on pervaporation-based product separation suggested that this process potentially gives a better result by the development of a closed reactor-pervaporation membrane coupled system, which enables continuous in situ fermentation and product separation [22-24]. Polydimethylsiloxane (PDMS) membrane is of interest for this purpose primarily due to its stability and low price. Works on separate pervaporations showed that silicalite and silicone membranes, which were more readily available, could give promising yields $[25,26]$. Another interesting approach in product separation from the fermenter is the in situ stripping process $[9,27,28]$. Among benefits provided by this method were the indirect agitation effect given by the sparged stripping gas that reduced impeller works, the use of non-toxic separation medium, and relatively simple equipment set-up.

Several available works compared the energy performance of the product separation process $[1,4,8,10,13]$. However, researchers have agreed that direct comparison among the available literature is hard due to the various operating conditions and system assumptions used [18]. Despite that, studies related to the overall economic impact on specific technologies applied in the biobutanol production plant are still lacking. For instance, it is not necessarily that the process with the lowest energy consumption will have the lowest production cost if the consumables (extractant, adsorbent, and membrane) are expensive. Therefore, in this study, techno-economic analysis of different pretreatment and product separation technologies were conducted for butanol production from oil palm frond (OPF).

\section{Materials and Methods}

\subsection{Software Tools}

The butanol production plant simulation and cost modeling analyses were conducted using SuperPro Designer V.9.0 (Intelligen, Inc., Scotch Plains, NJ, USA).

\subsection{Techno-Economic Analysis (TEA)}

The economic evaluation of butanol production from OPF was conducted based on $95.34 \times 10^{6} \mathrm{~L}$ butanol/y production plant capacity. Different pretreatment and product separation approaches were simulated. Figure 1 highlights the pretreatment and product separation stages in the modeled cellulosic butanol plant. All models were simulated in a continuous mode of operation with independent cycle time for most of the unit operation. It was assumed that the production plant is located in Pahang, Malaysia, where approximately 732,052 hectares of oil palm plantation area are available [29]. All analysis was done based on a functional unit of $1 \mathrm{~L}$ butanol.

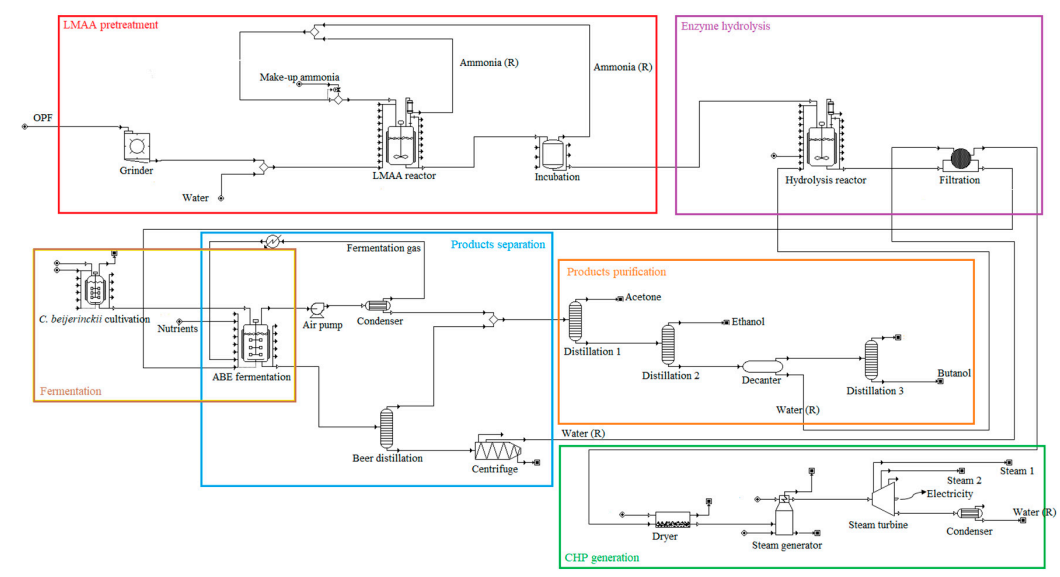

Figure 1. Major unit operations used in the SuperPro simulations. Different colored boxes denote different production stages; (R)—recycle. Note that this figure only includes major unit operations. More thorough plant set-ups were used in the simulations. 


\subsection{Pretreatment Approaches}

The simulation was started at the point the pre-milled OPF arrived at the production facility. The OPF was assumed to have been pre-milled and cleaned by the supplier. The assumption was applied to reduce the extensive milling requirement that must be incurred by the processing plant due to the morphology of OPF. Only rough milling by hammer mill was conducted before the pretreatment process. Different pretreatment approaches were selected based on available literature on the pretreatment of OPF, which includes LMAA pretreatment, autohydrolysis pretreatment, soaking in aqueous ammonia (SAA) pretreatment, and soaking in sodium hydroxide $(\mathrm{NaOH})$ pretreatment. For every pretreatment model simulated, the same enzyme hydrolysis and in situ stripping product separation processes were applied. The untreated OPF was assumed to have $51 \%$ cellulose, $17 \%$ hemicellulose, and $26 \%$ lignin.

\subsubsection{Low-Moisture Anhydrous Ammonia (LMAA) Pretreatment}

The moisture content of OPF was adjusted to $50 \%$ (dry basis) by mixing with water. Ammoniation was conducted by introducing $0.18 \mathrm{~g} \mathrm{NH}_{3} / \mathrm{g}$ biomass into the reactor for $1 \mathrm{~h}$, after which it was incubated at $75^{\circ} \mathrm{C}$ for $24 \mathrm{~h}$. All selected process parameters were from previous works and have been validated in the laboratory [30-32]. Continuous stirred tank reactors (CSTR) were used to simulate the ammoniation process, while the incubation process was simulated using heated storage tanks. A $90 \%$ recycle $\mathrm{NH}_{3}$ was achieved through a compressor unit installed at each of the ammoniation and incubation tanks [16]. The pretreatment recorded a $17.6 \%$ increase in cellulose, a $27.4 \%$ reduction in hemicellulose, and a $58.9 \%$ reduction in lignin contents.

\subsubsection{Autohydrolysis Pretreatment}

Autohydrolysis pretreatment was conducted according to [33]. OPF with water added at a ratio of 1:10 was heated at $121^{\circ} \mathrm{C}$ and $15 \mathrm{psi}$ for $1 \mathrm{~h}$. CSTR was used to simulate the autohydrolysis pretreatment process, after which the OPF slurry was cooled and fed to the rotary filtration unit to reduce the water content. The process was reported to recover $75 \%$ of insoluble solids, with the total cellulose, hemicellulose, and lignin contents reduced by $1.3 \%, 61.9 \%$, and $12.3 \%$, respectively, from those of the untreated sample.

\subsubsection{Soaking in Aqueous Ammonia (SAA) Pretreatment}

SAA pretreatment was conducted according to [34]. In a reaction tank, $7 \%$ aqueous $\mathrm{NH}_{3}$ and OPF at 1:12 (S/L ratio) were added and left to react at $80^{\circ} \mathrm{C}$ for $20 \mathrm{~h}$. CSTR was used to simulate the SAA pretreatment process, after which the OPF slurry was cooled and fed to the rotary filtration unit with a water washing stream for detoxification. The process was reported to recover $81.7 \%$ of insoluble solids, with the total cellulose, hemicellulose, and lignin contents reduced by $9.4 \%, 31.4 \%$, and $24.6 \%$, respectively, from those of the untreated sample.

\subsubsection{Soaking in Sodium Hydroxide $(\mathrm{NaOH})$ Pretreatment}

$\mathrm{NaOH}$ pretreatment was conducted according to [35]. OPF was soaked in $4.42 \%$ sodium hydroxide $(\mathrm{NaOH})$ solution at $100{ }^{\circ} \mathrm{C}$ for $\sim 1 \mathrm{~h}$. CSTR was used to simulate the $\mathrm{NaOH}$ pretreatment process, after which the OPF slurry was cooled and fed to the rotary filtration unit with a water washing stream for detoxification. The treated OPF was reported as having an increase of $46.7 \%$ and $22.7 \%$ in cellulose and hemicellulose, respectively, as well as $30.8 \%$ decrease in lignin content.

\subsection{Enzyme Hydrolysis and ABE Fermentation}

The treated OPF was hydrolyzed using cellulase enzyme according to [36]. The substrate concentration in the hydrolysis process was $15 \%$ (wt. OPF/v. water). Validation in the laboratory has shown that glucose yield after the hydrolysis process was about $0.33 \mathrm{~g} / \mathrm{g}$ treated OPF [32]. The hydrolysate mixture was separated from the fiber residue to ease the subsequent in situ product separation process. 
Full separation of sugars was obtained by cake washing with $3.0 v / v$ (water/cake) during the filtration process. The fiber-free solution was brought to the closed fermenter, where the required nutrients and microorganisms were supplied. Growth nutrients include yeast extract, potassium salts, and diammonium phosphate $[37,38]$. No added water was supplied to the fermenter because the cake-washing process has provided enough water for the reaction. The glucose concentration in the fermenter was $60 \mathrm{~g} / \mathrm{L}$. The ABE fermentation was conducted using Clostridium beijerinckii at $35^{\circ} \mathrm{C}$ for $72 \mathrm{~h}[37,39]$. Product yields were estimated according to the stoichiometric reactions Equations (1)-(5) [38]. Xylose conversion into products was not considered in the simulation due to lack of data. Three hydrolysis reactors (CSTR) and four fermenters were used in sequence to ensure continuous processing.

$$
\begin{gathered}
\text { Acetone } \mathrm{C}_{6} \mathrm{H}_{12} \mathrm{O}_{6}+\mathrm{H}_{2} \mathrm{O} \rightarrow \mathrm{CH}_{3} \mathrm{COCH}_{3}+3 \mathrm{CO}_{2}+4 \mathrm{H}_{2} \\
\text { Butanol } \mathrm{C}_{6} \mathrm{H}_{12} \mathrm{O}_{6} \rightarrow \mathrm{C}_{4} \mathrm{H}_{9} \mathrm{OH}+2 \mathrm{CO}_{2}+\mathrm{H}_{2} \mathrm{O} \\
\text { Ethanol } \mathrm{C}_{6} \mathrm{H}_{12} \mathrm{O}_{6} \rightarrow 2 \mathrm{C}_{2} \mathrm{H}_{5} \mathrm{OH}+2 \mathrm{CO}_{2} \\
\text { Acetic acid } \mathrm{C}_{6} \mathrm{H}_{12} \mathrm{O}_{6}+2 \mathrm{H}_{2} \mathrm{O} \rightarrow 2 \mathrm{CH}_{3} \mathrm{COOH}+2 \mathrm{CO}_{2}+4 \mathrm{H}_{2} \\
\text { Butyric acid } \mathrm{C}_{6} \mathrm{H}_{12} \mathrm{O}_{6} \rightarrow \mathrm{C}_{3} \mathrm{H}_{7} \mathrm{COOH}+2 \mathrm{CO}_{2}+2 \mathrm{H}_{2}
\end{gathered}
$$

\subsection{Product Separation Approaches and Downstream Processing}

The fermented mixture was processed using several in situ and inline product separation technologies, namely in situ stripping, dual extraction, membrane pervaporation, and adsorption. In each simulation comparing different product separation technologies, LMAA was used in the pretreatment section. Except for in situ stripping process, the fermentation broth from fermenter underwent filtration before the product separation process to allow recycling of the cells. The density of butanol, acetone, and ethanol was $810 \mathrm{~kg} / \mathrm{m}^{3}, 783 \mathrm{~kg} / \mathrm{m}^{3}$, and $789 \mathrm{~kg} / \mathrm{m}^{3}$, respectively [40]. The downstream processing part in the simulation was according to [41] with modification depending on the stream compositions.

\subsubsection{In Situ Stripping}

In situ stripping was conducted according to [9,42]. This process involves the use of fermentation gases $\left(\mathrm{CO}_{2}\right.$ and $\left.\mathrm{H}_{2}\right)$ to separate products from the fermentation broth. Fermentation gases were compressed and heated to $35{ }^{\circ} \mathrm{C}$ before purged into the bottom of the fermenter. As these gases move upwards, the fermenter will be stripping out the solvent products from the fermentation broth. A vacuum pump was used to facilitate gas exit from the upper part of the fermenter. The solvents were then condensed while the gases were recycled back to the fermenter.

According to [42], in situ stripping was capable of removing $\sim 81 \%$ acetone, $\sim 88 \%$ butanol, and $\sim 80 \%$ ethanol from the modeled ABE solutions. With an in situ stripping process, no product inhibition was assumed to occur, thus allowing maximum reactions where all acetic acid and butyric acid were converted to solvents [9]. The stripping cycle runs continuously throughout the fermentation, and the stripping gases were released to the environment once the fermentation was completed. The retired fermentation broth containing unstripped products underwent beer distillation following work by [14], for separation of the remaining products. The mixture of products was then processed in a series of distillation columns to separate and purify acetone, ethanol, and butanol. A decanter unit was used before the butanol distillation column to separate most of the water. The light phase from the decanter unit underwent butanol distillation column, while the heavy phase which mostly water was recycled throughout the processing. 


\subsubsection{Dual Extraction}

This process was selected due to its simplicity and straightforward simulation approach. Although [18] reported the high cost of high-pressure steam associated with this process, employment of the combined heat and power (CHP) system in this study would considerably reduce the cost. The simulation was conducted according to [3]. The fermentation broth was entering extraction-1 where most of the acetone, butanol, and ethanol will be separated. The organic stream proceeds to the regeneration column to recover the extractant-1. The aqueous phase from extraction-1 proceeded to extraction-2, where the remaining extractant- 1 was removed before recycling the broth back to the fermenter. Both extraction processes were conducted at $37^{\circ} \mathrm{C}$ and 1 bar.

Extractants used were 2-methyl-1-hexanol (non-biocompatible) and cyclopentane (biocompatible) for extraction-1 and extraction-2, respectively. The distribution coefficients for water, acetone, butanol, ethanol, acetic acid, butyric acid, and 2-methyl-1-hexanol in extractant-1 were $0.06,2.45,12.6,3.89,0.94$, 10.2 , and 150, respectively. The distribution coefficients for water, acetone, butanol, ethanol, acetic acid, butyric acid, 2-methyl-1-hexanol, and cyclopentane in extractant- 2 were $0.0002,0.37,1.47,1.00,0.15$, $0.79,664$, and 8313 , respectively. The mixture of products from the regeneration column underwent distillation where lowest boiling-point components (acetone and ethanol) were separated from the butanol-water mixture. The acetone-ethanol mixture then underwent distillation to purify both the acetone and ethanol. Because of high water content in the water-butanol mixture, a decanter was used to generate phase 2 in which the lighter phase (butanol) proceeded to distillation for purification.

\subsubsection{Adsorption}

ABE fermentation product separation using adsorption technology was based on work from [21,43]. AC F-400 was used as the adsorbent. Fermentation broth from the fermenter underwent filtration to allow recycling of the cell. The cell-free mixture was loaded into the adsorption column which is selective towards butanol and acetone. An optimistic condition was assumed (99\% recovery). Hot air $\left(150^{\circ} \mathrm{C}\right)$ was purged into the adsorption column to desorb the acetone and butanol, and regenerate the adsorbent. The stripped air containing acetone and butanol was condensed before going through a series of distillations. Column equilibration was conducted using water at room temperature before the next cycle of the adsorption process. The butanol- and acetone-depleted solution from the adsorption column proceeded to the ethanol distillation.

\subsubsection{Membrane Pervaporation}

The external pervaporation (PV) process was simulated following work from [26]. A silicone membrane was used with the assumed shelf-life of 100 cycles. The product-containing fermentation broth was heated to $80^{\circ} \mathrm{C}$ before being fed to the PV unit. The silicone membrane was reported to be able to separate acetone, butanol, ethanol, butyric acid, and acetic acid from the fermentation broth with varied selectivities [26]. In this simulation, an optimistic condition was assumed on the PV membrane, where it could achieve $~ 99 \%$ separation efficiency for all products. Compressed air was introduced to remove diffused products from the membrane surface. The product-free broth was then recycled to the fermenter. The mixture of products was processed in a series of distillation columns to separate and purify acetone, ethanol, and butanol.

\subsection{Power, Heating, and Cooling Requirement}

The remaining lignin and other solid residues (undigested cellulose and hemicellulose) separated from the fermentable sugar after enzyme hydrolysis were used as a fuel for the CHP generation system. It was dried to approximately $10 \%$ moisture content before fed to the CHP system. The CHP 
system was also supplemented with natural gas because burning only waste fibers did not generate enough steam for the entire production plant. The actual Rankine Cycle consisting of a boiler unit, and a multistage steam turbine was used and simulated using SuperPro built-in expansion models. The generator was assumed to be $90 \%$ efficient.

The compositions of the waste fibers were lignin $(\sim 18 \%)$, undigested cellulose $(\sim 58 \%)$, hemicellulose $(\sim 11 \%)$, and the rest were moisture and ash. The elemental compositions for lignin, cellulose, hemicellulose, and natural gas used in the simulation were summarized in Table 1. Air and water at a pressure of 1 bar and 11 bar, respectively, and atmospheric temperature entered the boiler at a rate calculated by the software. The generated high-pressure and high-temperature steam ( 45 bar, $257.44^{\circ} \mathrm{C}$ ) was expanded in a multistage steam turbine to produce electricity as well as steam with specific pressures. The cooling and chilled water requirement for the process were fulfilled by the on-site cooling tower and electric cooling, respectively.

Table 1. Elemental compositions of fuels used for the boiler.

\begin{tabular}{ccccc}
\hline Elements & Lignin (\%) [44] & Cellulose (\%) [45] & Hemicellulose (\%) [45] & Natural Gas (\%) [46] \\
\hline Carbon & 58.45 & 44.40 & 45.50 & 75.85 \\
Hydrogen & 6.80 & 6.20 & 6.10 & 24.15 \\
Nitrogen & 1.12 & - & - & - \\
Oxygen & 33.63 & 49.40 & 48.40 & - \\
\hline
\end{tabular}

\subsection{Sensitivity Analysis}

The sensitivity of selected processes at $\pm 20 \%$ parameter values were conducted to address any possibility for uncertainty. Among parameters included were costs of pretreatment agents, membrane cost (pervaporation), extractant cost (dual extraction), the presence of xylose, hydrolysis yield, pretreatment yield, and land cost. For the presence of xylose, $20 \%$ xylose content was assumed to be obtained from the conversion of hemicellulose that was recovered after each pretreatment process. Only those simulations with promising butanol production cost (less than $\$ 2.50 / \mathrm{L}$ ) were subjected to this study. Sensitivity analysis was also conducted on the profit of the simulated plant. The biobutanol selling price of $\$ 1.73 / \mathrm{kg}$ was applied [47].

\subsection{Assumptions and Limitations of the Study}

The techno-economic analysis was conducted with the assumption that the plant was built in Malaysia (location factor, LF $=1.14$ ) [48]. Capital expenditures $(\mathrm{CapEx})$, operating expenditures (OpEx), and production costs per unit of butanol were calculated based on assumptions in Table 2. Based on the level of detail of the modeled plant, small equipment that were not considered explicitly were assumed to be $10 \%$ and $20 \%$ from the equipment purchased cost for upstream and downstream processing stages, respectively [49]. Professional and management labor costs were not included in the assessment.

No heat loss, leakage, or any accidents were assumed to happen throughout the processing year. Transportation cost was not included in the assessment. The C. beijerinckii was cultivated and maintained in the plant facility, thus purchase cost was not included. Nutrient costs were assumed at $\$ 200 / t$ each. Water was recycled throughout the production. Wastewater treatment cost, which might also include the neutralization process, was assumed to be $\$ 0.53 / \mathrm{m}^{3}$ [49]. By-product credit of $\$ 1.04 / \mathrm{L}$ ethanol price and $\$ 1.28 / \mathrm{kg}$ acetone price, and butanol price of $\$ 1.73 / \mathrm{kg}$ were applied [47]. Table 3 summarizes other assumptions used in the study. Costs for OPF and utilities were with reference to the prices in Malaysia, considering an exchange rate of $\$ 1.00=$ MYR 4.10 (January 2018). 
Table 2. Key assumptions used for the techno-economic analysis, adapted from [49,50].

\begin{tabular}{|c|c|}
\hline \multicolumn{2}{|c|}{ Capital Cost } \\
\hline Installation & $39 \% \times \mathrm{Ep}$ \\
\hline Instrument and Control & $26 \% \times \mathrm{Ep}$ \\
\hline Piping & $10 \% \times \mathrm{Ep}$ \\
\hline Electrical System & $31 \% \times \mathrm{Ep}$ \\
\hline Building & $29 \% \times \mathrm{Ep}$ \\
\hline Yard Improvement & $12 \% \times \mathrm{Ep}$ \\
\hline Service & $55 \% \times \mathrm{Ep}$ \\
\hline \multicolumn{2}{|c|}{ Total Installed Equipment Cost (TIEC) } \\
\hline Engineering & $32 \% \times \mathrm{Ep}$ \\
\hline Construction & $34 \% \times \mathrm{Ep}$ \\
\hline Legal and Contractor Fees & $23 \% \times \mathrm{Ep}$ \\
\hline \multicolumn{2}{|c|}{ Total Indirect Cost (TIC) } \\
\hline Contingency & $10 \% \times($ TIEC + TIC $)$ \\
\hline Fixed Capital Investment (FCI) & $($ TIEC + TIC + contingency $) \times$ LF \\
\hline Working Capital (WC) & $15 \% \times$ FCI \\
\hline Land & $6 \% \times \mathrm{Ep}$ \\
\hline Total Project Investment (TPI) & FCI + WC + Land \\
\hline \multicolumn{2}{|c|}{ Operating Cost } \\
\hline Maintenance and Repairs & $1 \% \times \mathrm{TPI}$ \\
\hline Materials & Unit cost of each materials $\times$ Total unit used \\
\hline Labor Cost & Wage rate $\times$ No. of operator $\times$ Working hours \\
\hline Utilities & Electricity cost + Heat cost + Cooling cost \\
\hline \multicolumn{2}{|c|}{ Total Direct Operating Cost } \\
\hline Overhead & $50 \% \times$ (labor + maintenance and repairs) \\
\hline Taxes & $2 \% \times \mathrm{TPI}$ \\
\hline Insurance & $0.46 \% \times \mathrm{TPI}$ \\
\hline Depreciation (D) & Straight line \\
\hline \multicolumn{2}{|c|}{ Total Indirect Operating Cost } \\
\hline Salvage & $15 \%$ \\
\hline Capital Charges (CC) & $\mathrm{TPI} \times i(1+i)^{\mathrm{n}} /\left((1+i)^{\mathrm{n}}-1\right)$ \\
\hline Annual Operating Cost & Total direct and indirect operating cost $+\mathrm{CC}+\mathrm{D}$ \\
\hline By-Product Credit & Amount by-product generated $\times$ Unit selling price \\
\hline Net Annual Operating Cost & Annual operating cost-By-product credit \\
\hline Unit Production Cost & Net annual operating cost/annual product \\
\hline
\end{tabular}

$\mathrm{Ep}=$ equipment purchased cost; $\mathrm{LF}=$ location factor; Total direct operating cost $=$ all variable operating cost; Total indirect operating $\cos \mathrm{t}=$ all fixed operating $\operatorname{cost} ; i=$ annual interest rate of the loan; $\mathrm{n}=$ loan payment period.

Table 3. Other assumptions used for the techno-economic analysis.

\begin{tabular}{cc}
\hline & Assumptions \\
\hline Annual Working Hours & 7920 \\
OPF Price & $\$ 0.032 / \mathrm{kg}[51]$ \\
Cellulase Price & $\$ 5 / \mathrm{kg}[38]$ \\
Ammonia Solution Price & $\$ 300 / \mathrm{t}[38]$ \\
Anhydrous Ammonia Price & $\$ 512 / \mathrm{t}[52]$ \\
Sodium Hydroxide Price & $\$ 450 / \mathrm{t}[53]$ \\
2-Methyl-1-Hexanol Price & $\sim \$ 1900 / \mathrm{t}[3]]^{*}$ \\
Cyclopentane Price & $\$ 1150 / \mathrm{t}[3]^{*}$ \\
Activated Carbon Price & $\$ 2000 / \mathrm{t}[54]$ \\
Silicone Membrane Price & $\$ 250 / \mathrm{m}^{2}$ \\
Electricity Price (to grid) & $\$ 0.08 / \mathrm{kWh}[55]$ \\
Water Price & $\$ 0.21 / \mathrm{m}^{3}[56]$ \\
Natural Gas Price & $\$ 0.004 / \mathrm{ft}^{3}$ \\
Annual Interest Rate & $0.08 \%[57]$ \\
Operator Wage Rate & $\$ 2.26 / \mathrm{h}[58]$ \\
Interest Year & $20 \mathrm{y}$ \\
Equipment Lifetime & $20 \mathrm{y}$ \\
\hline
\end{tabular}

* Currency exchange-1 GBP $=1.27$ USD (January 2018). 


\section{Results and Discussions}

The overall process flow diagram applied in this study is shown in Figure 1. Different pretreatment and product separation models used in this study are shown in Figures 2 and 3 , respectively. Simulations of different pretreatments were conducted using the same product separation approach, which was in situ stripping. Meanwhile, simulations of different product separation technologies applied the same pretreatment method, which was LMAA pretreatment.
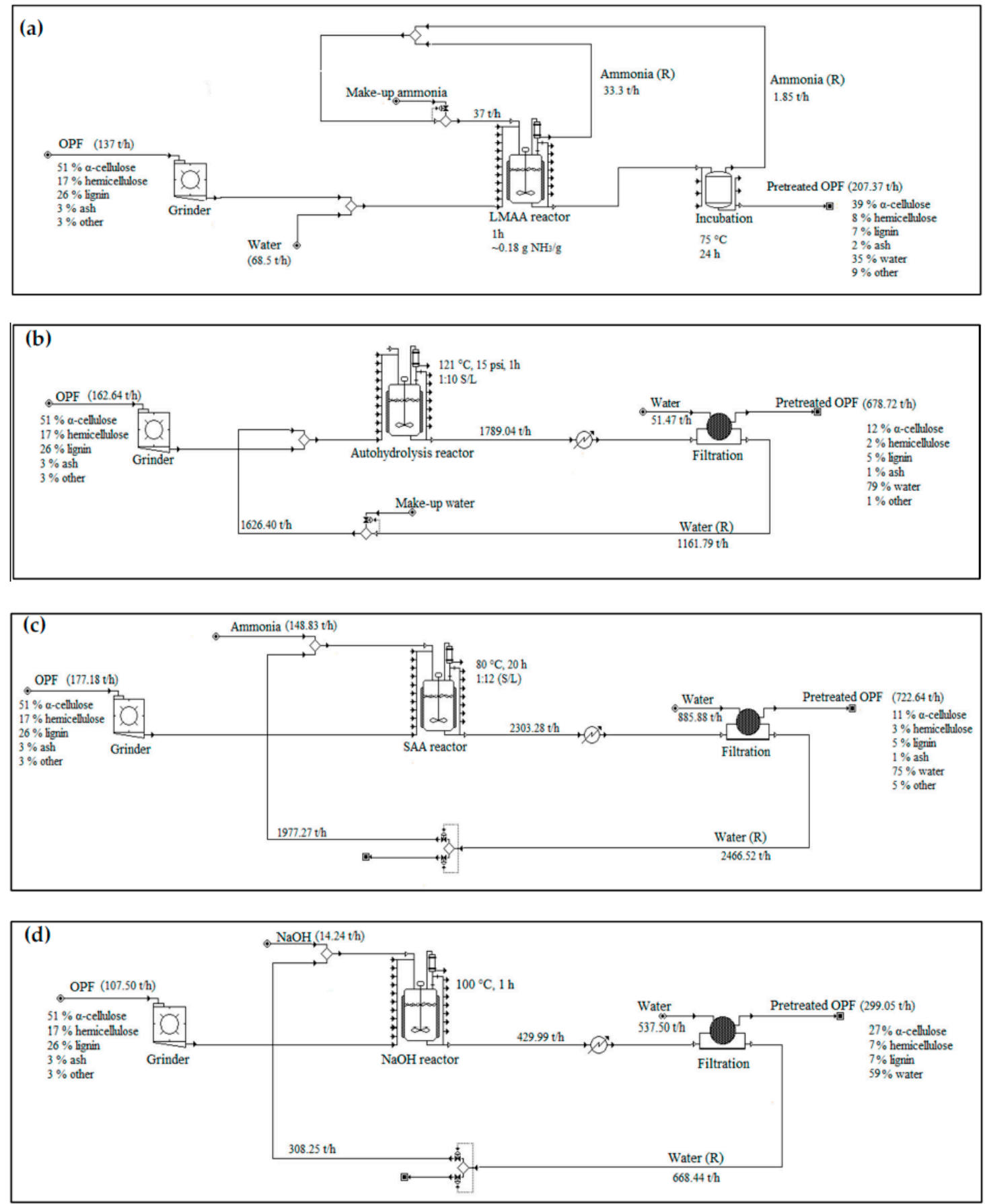

Figure 2. Pretreatment set-ups used in the simulations. Note that this figure only includes major unit operations. More thorough plant set-ups were used in the simulations. (a) LMAA; (b) autohydrolysis; (c) SAA; (d) $\mathrm{NaOH}$; OPF—oil palm frond; $\mathrm{SAA}$ - soaking in aqueous ammonia; $\mathrm{NaOH}$-soaking in sodium hydroxide solution; (R)—recycle. 
(a)

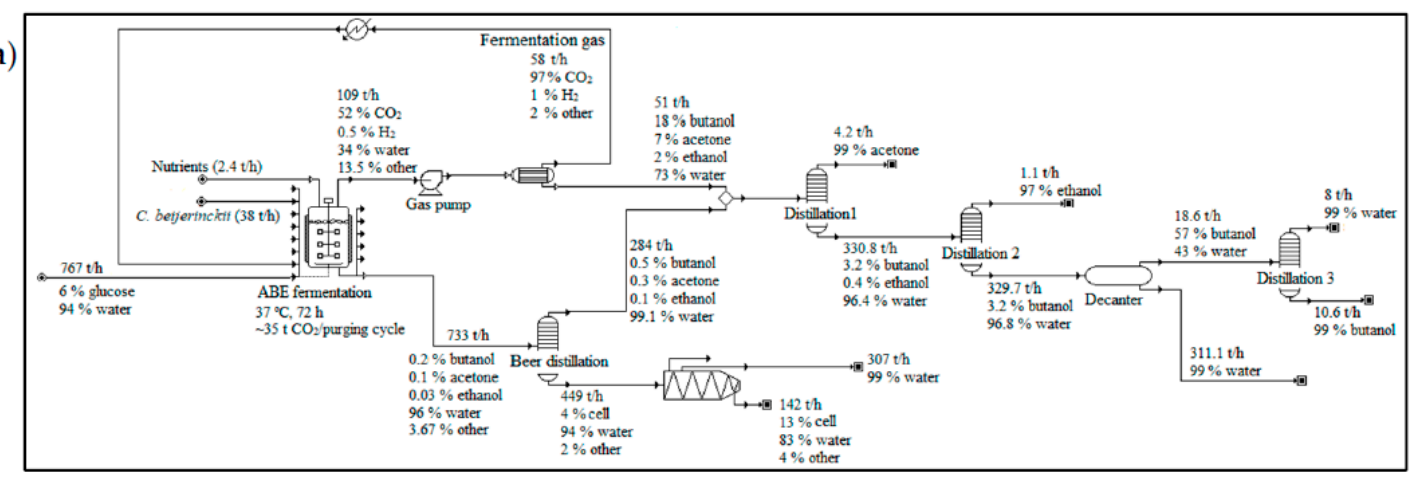

(b)

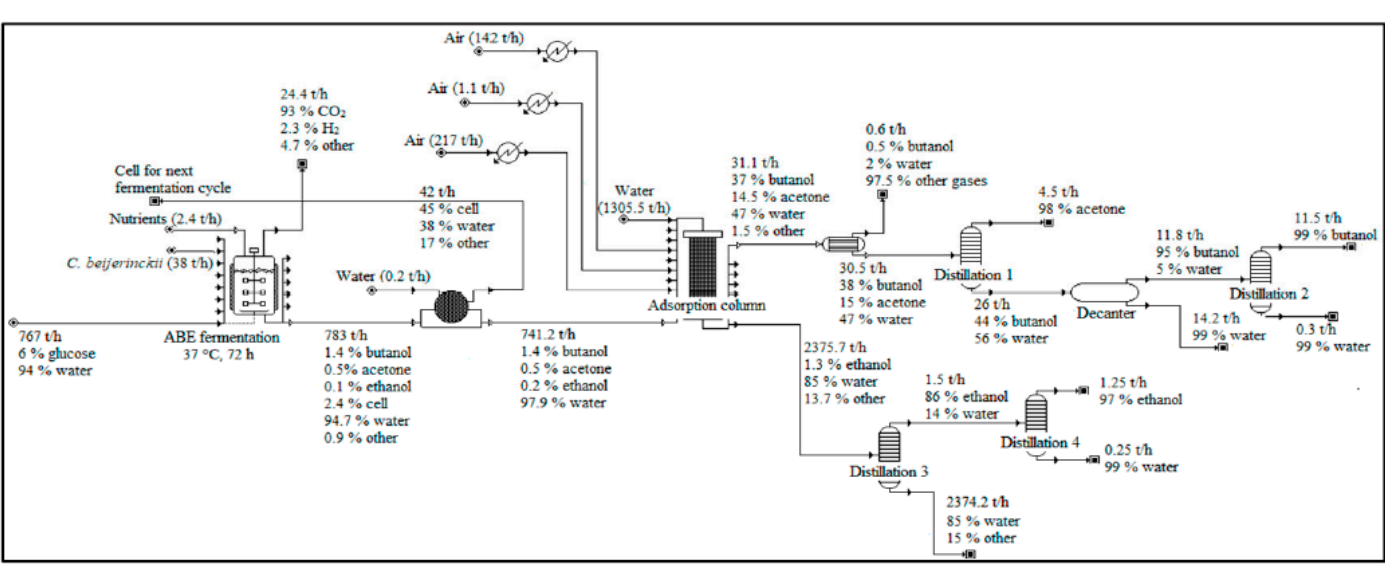

(c)

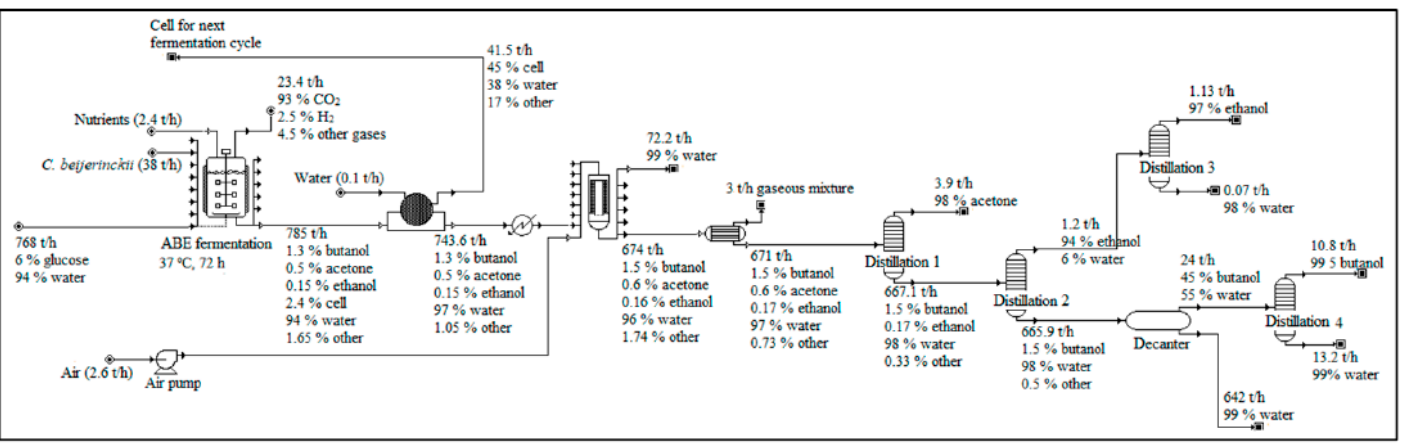

(d)

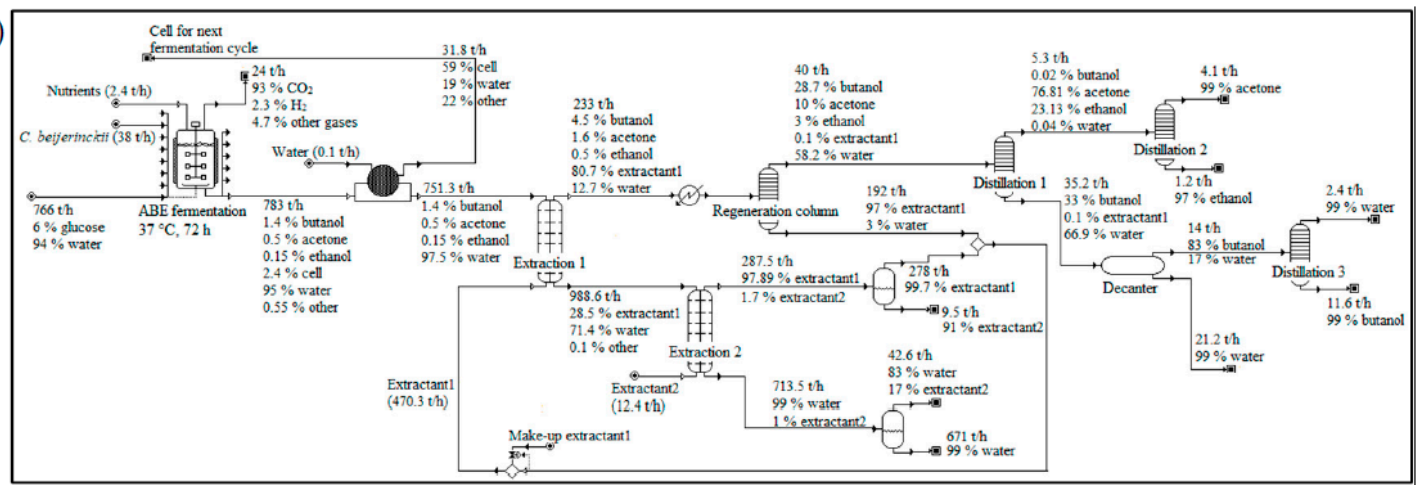

Figure 3. Product separation and purification set-ups used in the simulations. (a) in situ stripping; (b) adsorption-distillation; (c) pervaporation-distillation; (d) dual extraction-distillation. Note that this figure only includes major unit operations. More thorough plant set-ups were used in the actual simulations. 


\subsection{Comparison of Different Pretreatment Technologies}

\subsubsection{Production Costs of Butanol}

The previous simulation on ABE fermentation of LMAA-treated OPF [59] showed that $1.09 \times 10^{6} \mathrm{t}$ of OPF was required annually to produce $95.34 \times 10^{6} \mathrm{~L}$ butanol. When the same amount of OPF was subjected to different pretreatment technologies, different yields of butanol were recorded in each model simulation (see Figure 4). $\mathrm{NaOH}$ pretreatment model was the most efficient in giving high fermentation products, followed by LMAA, autohydrolysis, and SAA pretreatment models. For further analysis, plant scale of $95.34 \times 10^{6} \mathrm{~L}$ butanol/y was applied. To produce the desired butanol output, $1.29 \times 10^{6} \mathrm{t}, 1.40 \times 10^{6} \mathrm{t}$, and $0.85 \times 10^{6} \mathrm{t}$ of OPF were required annually by autohydrolysis, SAA, and $\mathrm{NaOH}$ pretreatment model, respectively. These values are equivalent to $10.52 \mathrm{~kg} / \mathrm{L} \mathrm{butanol}, 14.71 \mathrm{~kg} / \mathrm{L}$ butanol, $17.45 \mathrm{~kg} / \mathrm{L}$ butanol, and $6.72 \mathrm{~kg} / \mathrm{L}$ butanol, or, $6.93 \mathrm{~kg} / \mathrm{L} \mathrm{ABE}, 9.68 \mathrm{~kg} / \mathrm{L} \mathrm{ABE}, 11.49 \mathrm{~kg} / \mathrm{L} \mathrm{ABE}$, and $4.43 \mathrm{~kg} / \mathrm{L} \mathrm{ABE}$ of feedstocks required for LMAA, autohydrolysis, SAA, and $\mathrm{NaOH}$ pretreatment models, respectively.

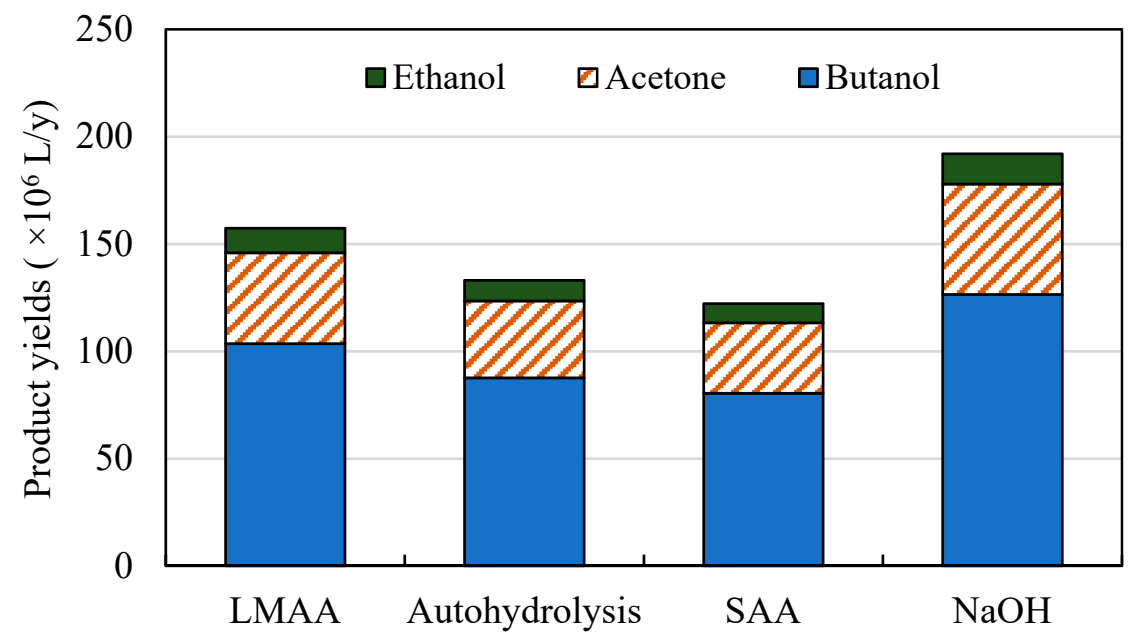

Figure 4. Product yields from ABE fermentation of OPF treated with different technologies. LMAA—low-moisture anhydrous ammonia; SAA—soaking in aqueous ammonia; $\mathrm{NaOH}$-soaking in sodium hydroxide solution.

Figure 5 shows the butanol production costs from the different pretreatment approaches simulated. Butanol production from SAA-treated OPF has the highest production cost $(\$ 5.28 / \mathrm{L})$, while those produced from LMAA-treated OPF has the lowest production cost $(\$ 1.58 / \mathrm{L})$ compared to the other pretreatments evaluated. The CapEx of all models simulated were almost similar. In contrast, there was considerable variation in OpEx between each model. Because the difference in each simulation was only in the pretreatment part, it could initially be deduced that different trends in OpEx were primarily caused by the specific pretreatment technologies applied.

The OpEx components for each pretreatment technologies in Figure 6, as well as results in Figure 7, justified the statement. For all models, other than the capital charges, utility costs, material costs, maintenance and repairs costs, and tax were among the largest cost contributors. Capital charges are the annual payments of loans (usually secured for CapEx) [50]. Therefore, it can be seen that the trends for capital charges were similar to those of CapEx. Utility costs involve the expense of purchasing natural gas and water for the CHP system as well as water for the cooling tower. Utility costs were observed to be directly related to the energy requirements of the process (see Figure 7). Autohydrolysis pretreatment model required more energy than the other models, which led to its high utility costs that were at least five times higher than those of other pretreatment models. 


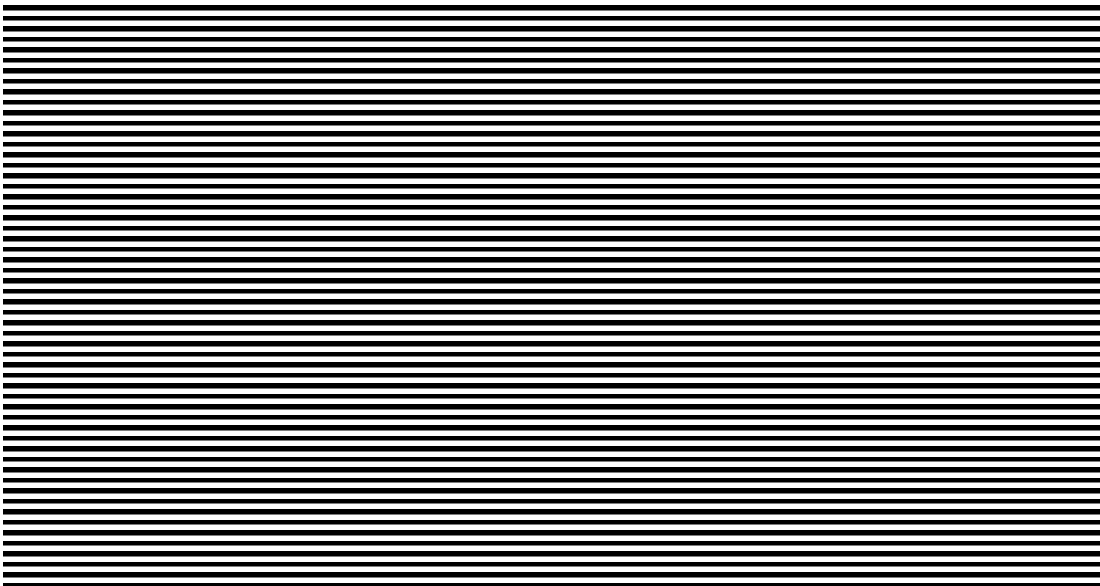

Figure 5. Production costs for butanol $(\$ / \mathrm{L})$ produced from OPF treated with different technologies. CapEx—capital expenditures; OpEx-operating expenditures; LMAA—low-moisture anhydrous ammonia; $\mathrm{SAA}$ —soaking in aqueous ammonia; $\mathrm{NaOH}$-soaking in sodium hydroxide solution.

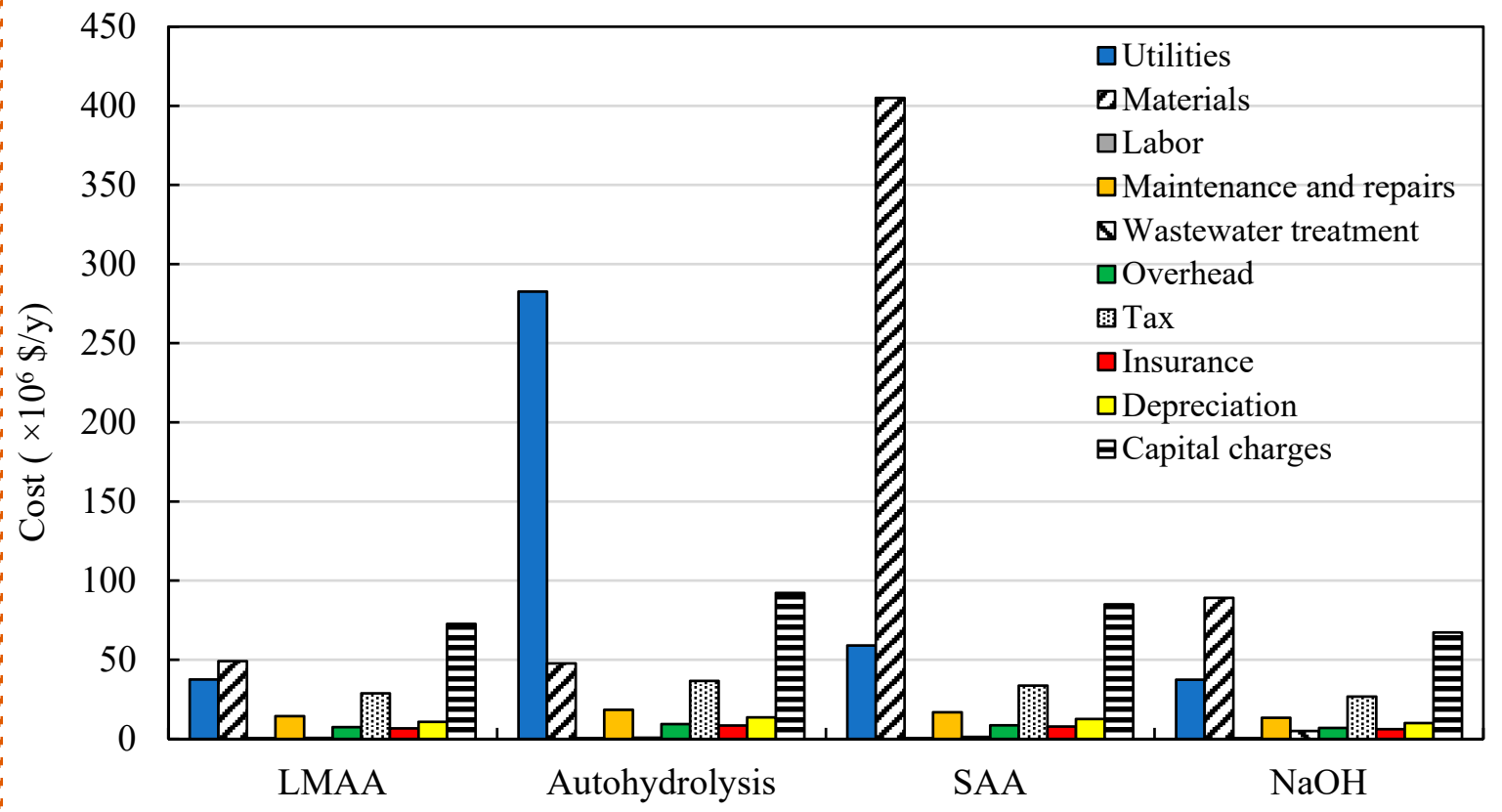

Figure 6. OpEx components of butanol produced from OPF treated using different technologies. LMAA—low-moisture anhydrous ammonia; SAA—soaking in aqueous ammonia; $\mathrm{NaOH} —$ soaking in sodium hydroxide solution.

Material costs (see Figure 6) involved the expense of feedstocks, pretreatment agents, growth nutrients, water used in the process, and other chemicals. Autohydrolysis pretreatment model recorded the lowest material costs primarily due to the use of only water as the pretreatment agent. Variation of material costs in other pretreatment models was due to different prices of each pretreatment agent and the ability to recycle it during the process.

LMAA pretreatment model required a low total amount of water, which was $3.9 \times 10^{6} \mathrm{~m}^{3} / \mathrm{y}$ in comparison to $8.2 \times 10^{6} \mathrm{~m}^{3} / \mathrm{y}, 10.8 \times 10^{6} \mathrm{~m}^{3} / \mathrm{y}$, and $7.4 \times 10^{6} \mathrm{~m}^{3} / \mathrm{y}$ of water for autohydrolysis, SAA, and $\mathrm{NaOH}$ pretreatment, respectively. Nevertheless, this had not led to the lowest material costs in the LMAA pretreatment model, which could indicate that the cost contribution from purchasing water is not critical in assessing the butanol production cost. Other materials, such as pretreatment agents, have a more considerable contribution to the butanol production cost. For instance, in autohydrolysis 
pretreatment, more water was required than those in LMAA pretreatment. However, it has lower material costs due to no chemical pretreatment agent used.

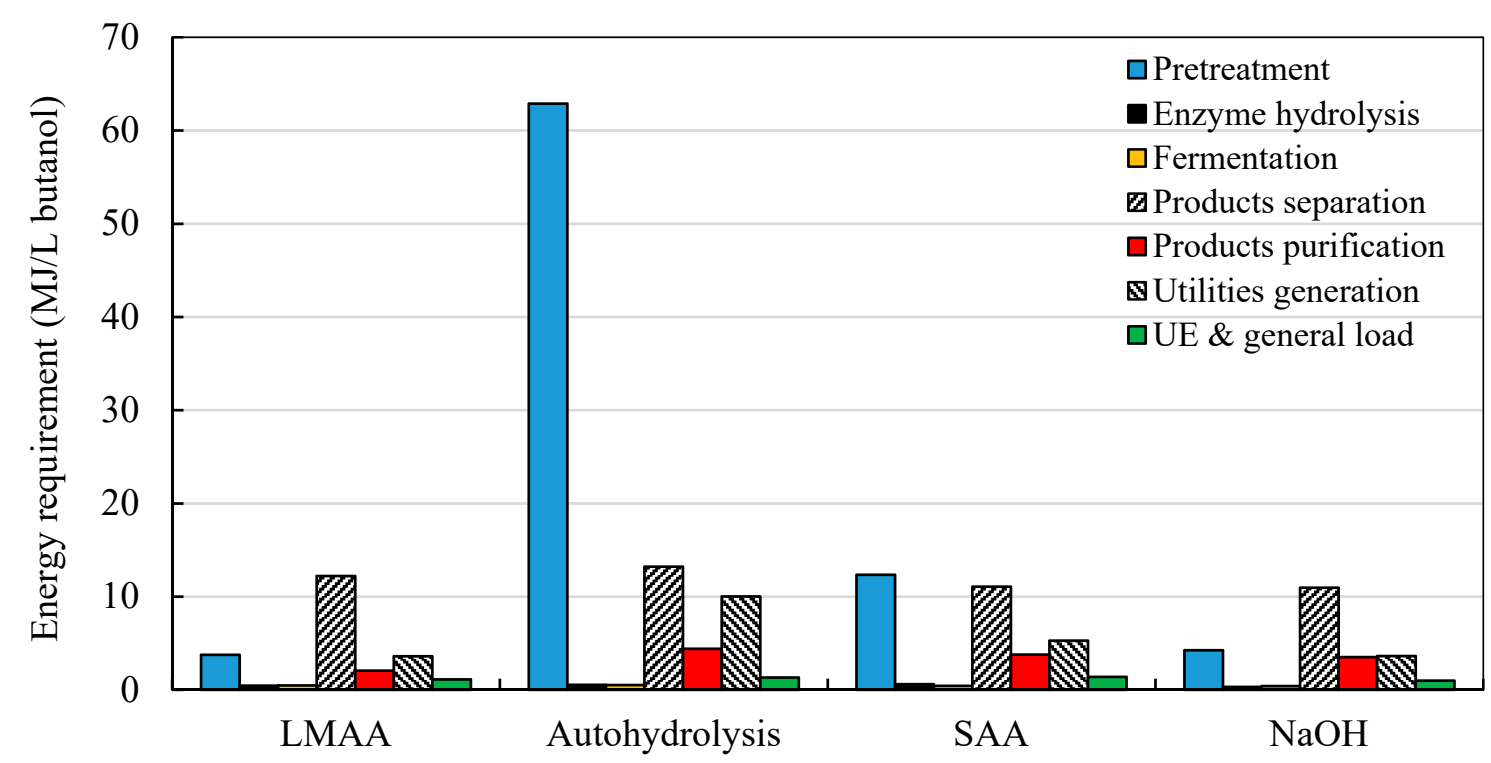

Figure 7. Energy requirements for each processing stage in the simulated butanol production from OPF treated with different technologies. LMAA—low-moisture anhydrous ammonia; SAA—soaking in aqueous ammonia; $\mathrm{NaOH}$-soaking in sodium hydroxide solution; UE-unlisted equipment.

Labor, wastewater treatment, overhead, and insurance costs were less important and almost similar for all pretreatment technologies simulated. LMAA pretreatment model recorded the lowest butanol production cost, followed by those of $\mathrm{NaOH}$ pretreatment model $(\$ 1.79 / \mathrm{L})$. With a substantial reduction in the price of pretreatment agent and conducted at a lower temperature, $\mathrm{NaOH}$ pretreatment potentially gives better butanol production costs.

By contrast, SAA pretreatment simulated in this study used a high solid-to-liquid (S/L) ratio, which led to the high material cost (see Figure 6), and eventually high butanol production cost. The butanol production cost recorded by LMAA pretreatment model, although the lowest compared to those of other simulated models, was higher than ethanol production cost from LMAA-treated corn stover reported by [60], which was $\sim 1.30 / \mathrm{L}$. It is known that butanol fermentation has lower productivity than ethanol fermentation. Therefore, a more significant reduction in butanol production cost might be achieved through better fermentation yield rather than pretreatment yield.

\subsubsection{Energy Requirements}

Figure 7 shows the total energies required (electricity and steam) by each processing stage. In agreement with the earlier statement, a considerable variation of energy usage was coming from the pretreatment stage with autohydrolysis pretreatment model recording the highest energy consumption. In addition to that, all other processing stages in the autohydrolysis model also consumed the highest energy per liter of butanol (although not far different) compared to the same processing stages in other pretreatment models. Autohydrolysis pretreatment has among the lowest efficiency (in recovering more cellulose during the pretreatment process), as well as conducted at high temperature and water loading than the other pretreatments, which eventually affected the subsequent processing stages in the production plant. Product separation and purification stages were the most affected with total energy consumption between 2.8-3.3 MJ/L higher than downstream processing stages in other simulation models. 
Pretreatment stage in the LMAA pretreatment model consumed the lowest energy; however, this was not the case for most of the rest of the processing stages. In general, except for the pretreatment stage, all other processing stages of each model had a similar trend of energy consumption with mostly small variations between each. Most of these variations were due to the slightly different stream compositions throughout the processing and different final product yields. For instance, a higher content of water in the purification unit demanded more energy for distillation, and higher fiber content in the hydrolysis reactor demanded higher power for agitation. LMAA pretreatment consumed in total the lowest energy per unit butanol produced followed by $\mathrm{NaOH}, \mathrm{SAA}$, and autohydrolysis pretreatments, with the amount of $23.75 \mathrm{MJ} / \mathrm{L}, 24.13 \mathrm{MJ} / \mathrm{L}, 34.97 \mathrm{MJ} / \mathrm{L}$, and $92.93 \mathrm{MJ} / \mathrm{L}$, respectively.

Figure 8 illustrates the utility cost fractions for each pretreatment technology with an on-site energy generation system fueled by fiber residues only (a) and a combination of fiber residues and natural gas (b). The use of natural gas in addition to the fiber residues as fuels for the CHP generation system in all models has demanded slightly higher capital cost (not shown) as well as costs for purchasing natural gas and water, compared to the expense required for outsourcing the steam.

(a)

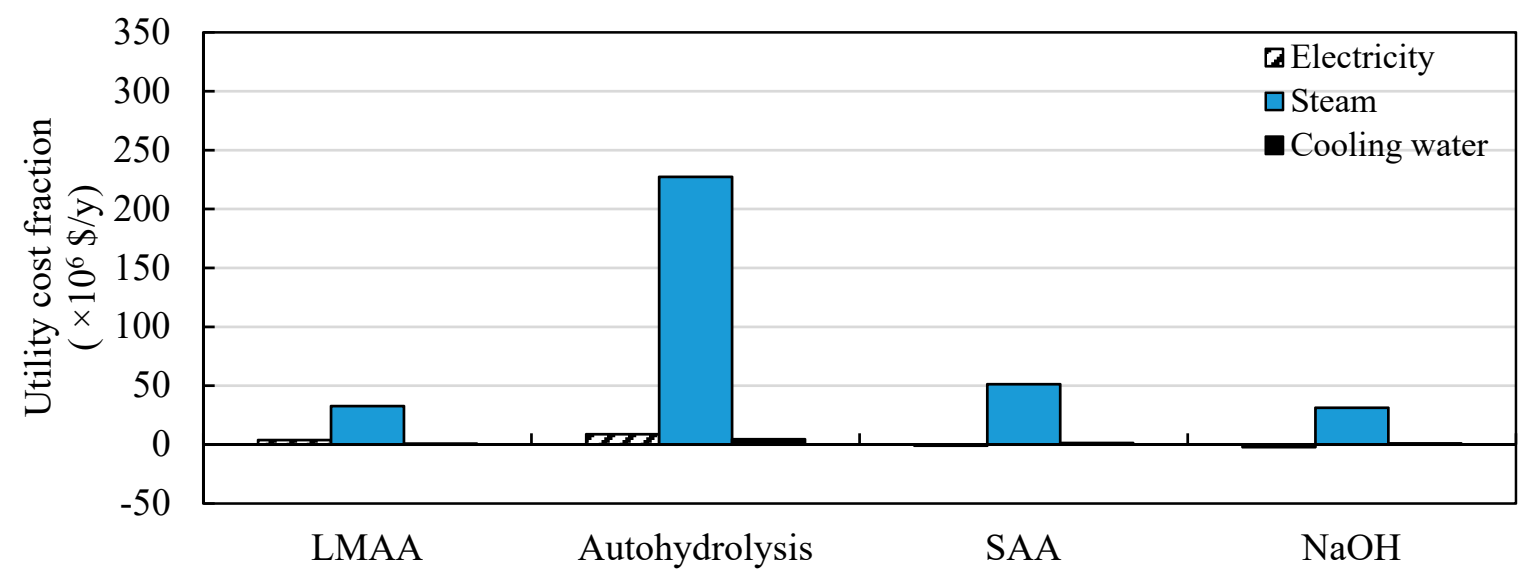

(b)

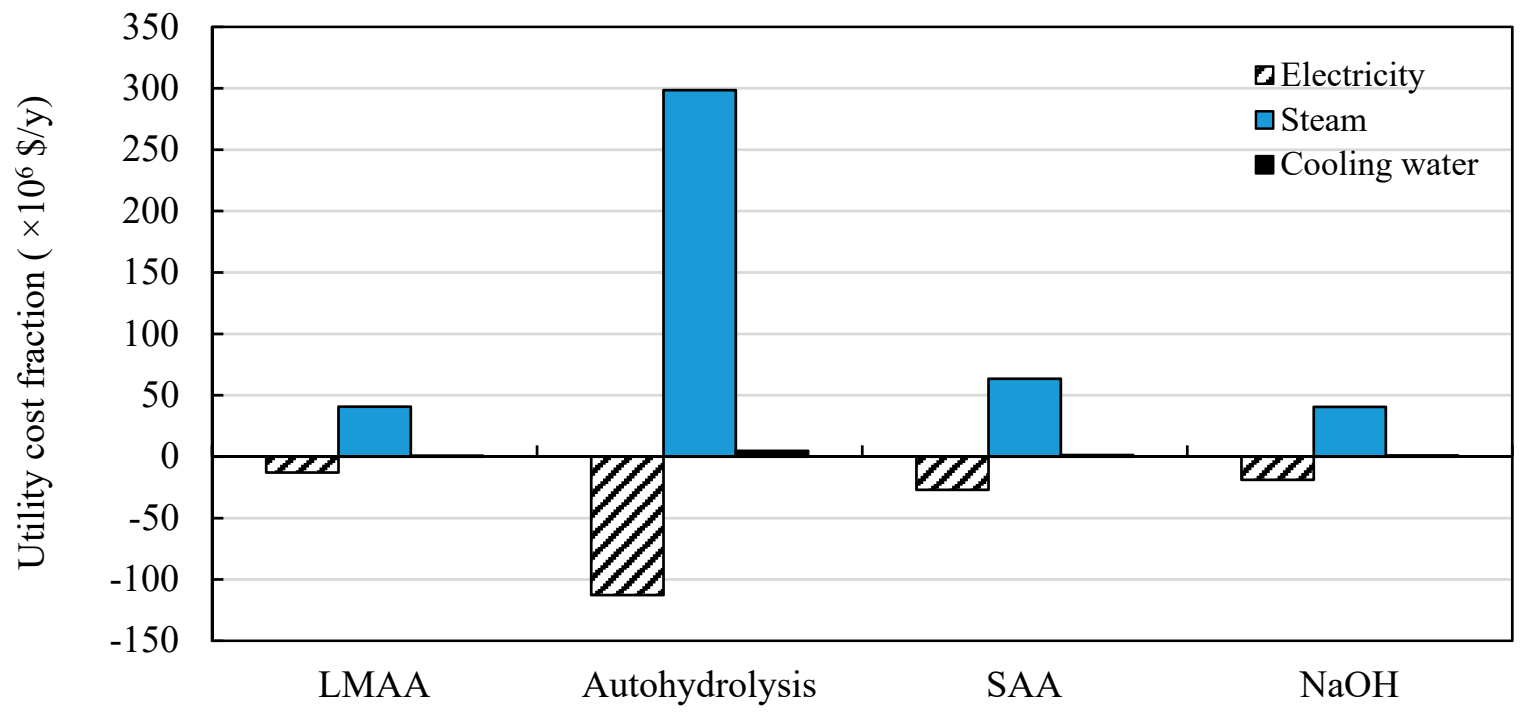

Figure 8. Utility cost fractions of butanol produced from OPF treated with different technologies. (a) with partial CHP generation system, and (b) with full CHP generation system; LMAA - low-moisture anhydrous ammonia; $\mathrm{SAA}$ — soaking in aqueous ammonia; $\mathrm{NaOH}$ —soaking in sodium hydroxide solution. 
However, the CHP system also generated an excessive amount of electricity, which is sold to the grid for an additional income. By burning only waste fibers in the CHP system, only $44 \%, 18 \%, 46 \%$, and $53 \%$ of steam needs could be fulfilled in LMAA, autohydrolysis, SAA, and $\mathrm{NaOH}$ pretreatment models, respectively. In general, for each technology, high requirement of heating was followed by high demand for cooling (i.e., those with the highest heating works will require the highest amount of cooling water). Reduction of the extent of heating and cooling could be achieved through better heat integration, which allows better heat recovery to be used in process streams requiring less critical heat. Optimization of this aspect was not conducted in this study.

As mentioned before, fiber residues and natural gas were used as fuels in the CHP system. For the autohydrolysis model, which required a considerably larger amount of heat, more natural gas was needed as compared to other simulated models. Approximately $68.89 \times 10^{9} \mathrm{ft}^{3}$ natural gas was needed annually by the autohydrolysis pretreatment model. In comparison, LMAA, SAA, and $\mathrm{NaOH}$ pretreatment model required an annual natural gas amount of around $9.15 \times 10^{9} \mathrm{ft}^{3}, 14.37 \times 10^{9} \mathrm{ft}^{3}$, and $9.11 \times 10^{9} \mathrm{ft}^{3}$, respectively. Approximately only $0.1 \%$ of cooling water increased was recorded for all models when the CHP generation system was the sole energy source. This value reflects the amount of cooling required by the condenser in the CHP system, which needed to allow for water recycling.

\subsection{Comparison of Different Product Recovery Technologies}

\subsubsection{Production Costs of Butanol}

In the study of comparison of different product separation technologies for the butanol production plant, $1.09 \times 10^{6} \mathrm{t}$ of OPF was used annually in all models. The adsorption model recorded the highest total product yields, followed by dual extraction, pervaporation, and in situ stripping models (see Figure 9). Nevertheless, focusing only on butanol yield, dual extraction process gave the highest yield followed by adsorption, pervaporation, and in situ stripping process. Despite that, the lowest butanol production cost (see Figure 10) was given by in situ stripping $(\$ 1.58 / \mathrm{L})$, while pervaporation and dual extraction model gave a slightly higher butanol production cost of $\$ 1.86 / \mathrm{L}$ and $\$ 1.70 / \mathrm{L}$ respectively. The butanol production cost recorded by adsorption model was the highest $(\$ 6.29 / \mathrm{L})$, due to a high amount of both CapEx and OpEx.

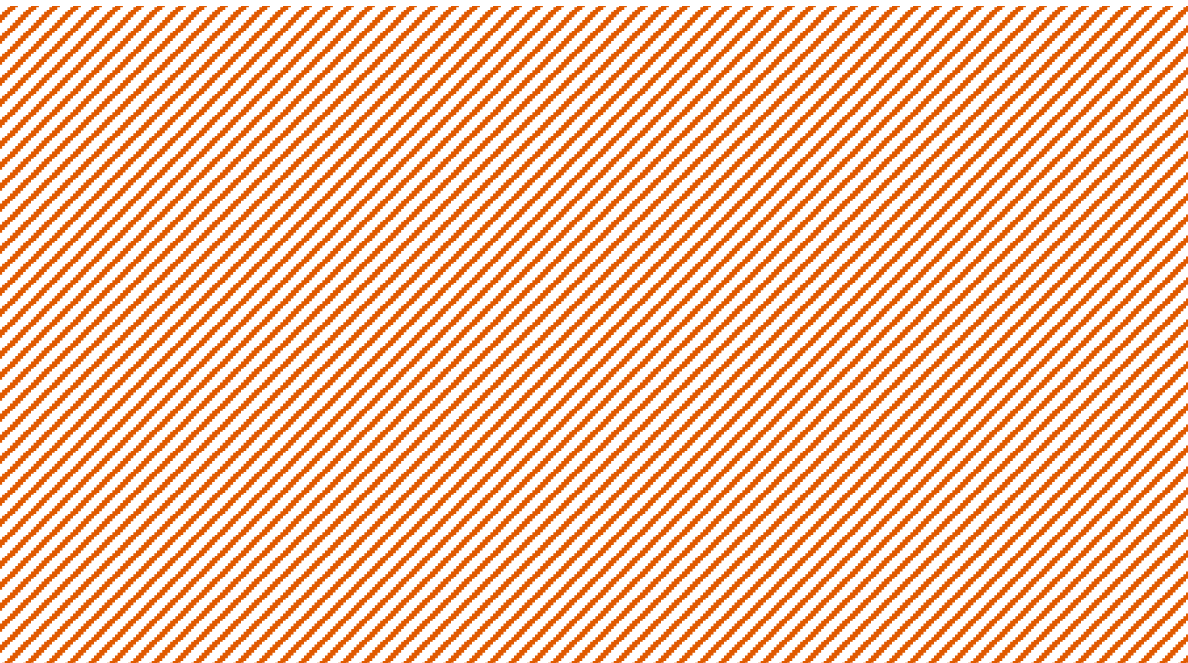

Figure 9. Product yields from ABE fermentation of LMAA-treated OPF simulated using different product separation technologies.

In the simulation, maximum product separation ( $99 \%)$ was assumed for the adsorption and pervaporation model. Nevertheless, the changes in butanol production cost if the recoveries are $80 \%$ and $90 \%$ were also calculated (see Figure 11). When the recoveries percentages were reduced to $80 \%$ 
and $90 \%$, adsorption model was observed to give higher butanol production cost increase than that for pervaporation model.

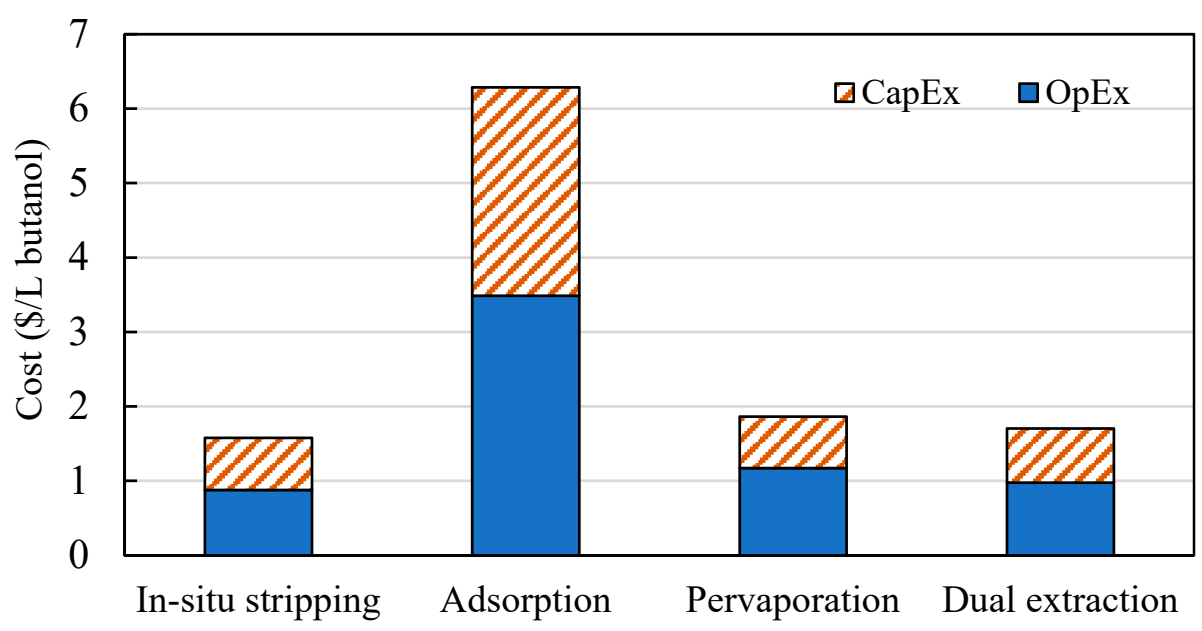

Figure 10. Production cost of butanol $(\$ / \mathrm{L})$ from ABE fermentation of LMAA-treated OPF simulated using different product separation technologies. CapEx—capital expenditures; OpEx—operating expenditures.

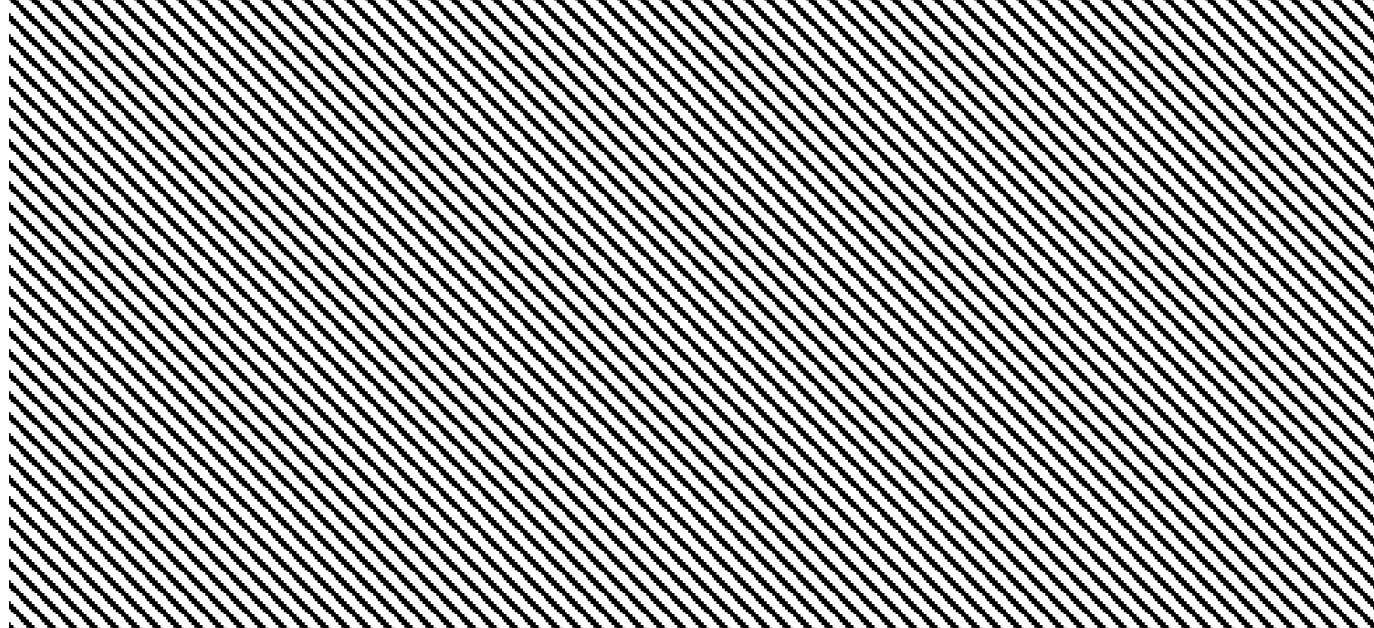

Figure 11. Production costs for butanol upon variation in product separation percentages in pervaporation and adsorption.

A considerably large fraction of CapEx was contributed by the product separation stage in adsorption model, which was not the case in the other models (see Figure 12). The CapEx for all other technologies was not far different between each, with the value in the range of $\sim \$ 0.69-0.73 / \mathrm{L}$. A similar trend was observed for the OpEx, where in situ stripping, dual extraction, and pervaporation model recorded a cost in the range of $\$ 0.88-1.17 / \mathrm{L}$, while those of adsorption model was substantially higher $(\$ 3.49 / \mathrm{L})$.

The OpEx cost components in Figure 13 presents the variation in cost spent by each processing stage. Each cost component in the adsorption model was higher than those recorded in the other models. The material and consumable costs in this model were not far different than those of the pervaporation model; however, because of the substantially high CapEx contribution in adsorption model (see Figure 12), the maintenance and repair costs, overhead cost, taxes, and insurance incurred in this model as compared to the other models was also considerably increased. 


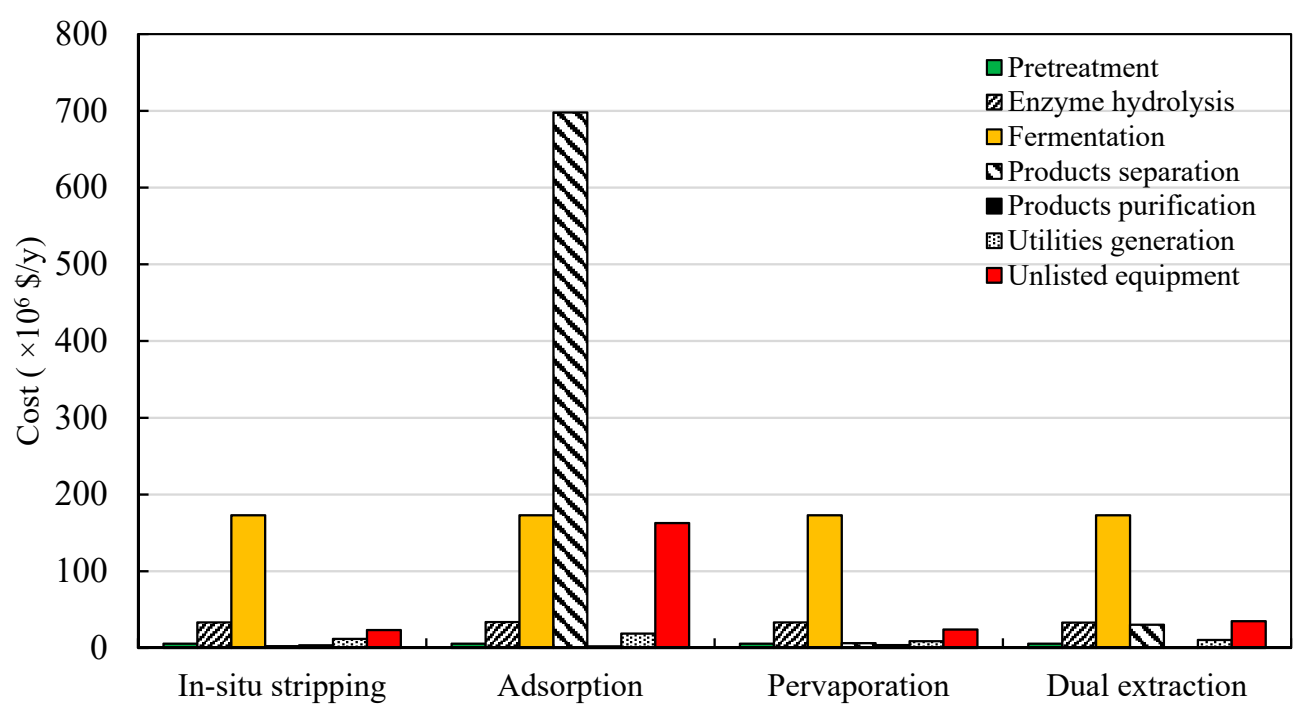

Figure 12. Components of CapEx for butanol production through ABE fermentation of LMAA-treated OPF simulated using different product separation technologies.

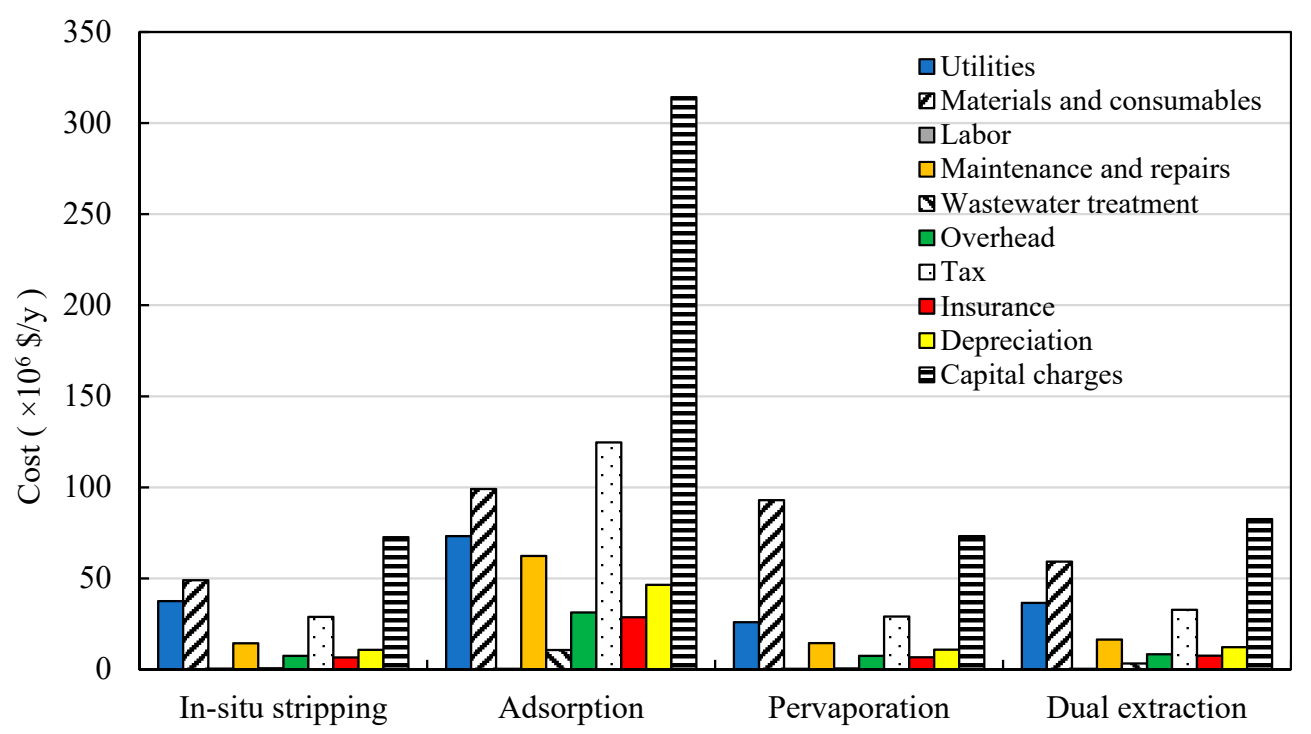

Figure 13. Components of OpEx for butanol production through ABE fermentation of LMAA-treated OPF simulated using different product separation technologies.

Reduction in butanol production cost in pervaporation model could be achieved mainly through a lower pervaporation membrane cost. By contrast, to reduce the butanol production cost in the adsorption model, several strategies must be applied primarily by getting a lower price for adsorption set-up and having lower adsorbent cost at the same or better separation efficiencies. For dual extraction model, the use of two different solvents at the simulated extraction conditions led to butanol production cost that was higher than those of in situ stripping model.

\subsubsection{Energy Requirements}

Figure 14 illustrates the energy consumption distribution in each simulated model of different product separation technologies. Note that the energy requirements were assessed from the simulation data. The reduction of energy requirement by subtracting the energy content of the products (net energy value) was not conducted. The most critical processing stages were product separation and purification (downstream processing) with a notable variation of energy required between each model. The highest energy consumption was recorded by the adsorption model (see Figure 13). It was primarily 
contributed by the product purification section $(20.42 \mathrm{MJ} / \mathrm{L})$, while its product separation stage used $0.37 \mathrm{MJ} / \mathrm{L}$. The same trend was recorded by pervaporation model with the energy requirement of the product purification stage $(9.36 \mathrm{MJ} / \mathrm{L})$ was multiple degrees higher than those of product separation stage $(1.71 \mathrm{MJ} / \mathrm{L})$.

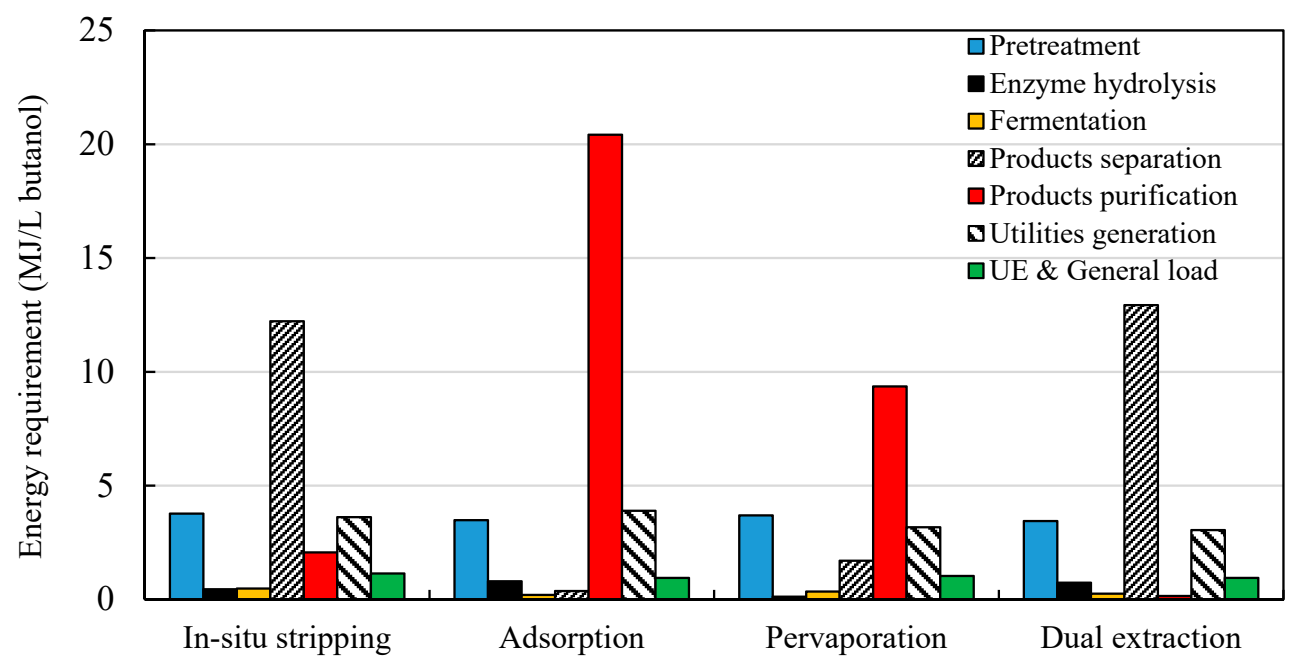

Figure 14. Energy requirements from each processing stage for simulated butanol production using different product separation technologies. UE-unlisted equipment.

The in situ stripping and dual extraction model recorded contrary results with product separation stage requiring the highest energy. Oudshoorn et al. [13] had calculated the energy requirement of butanol separation at various conditions. They assessed gas stripping, pervaporation, extraction, and adsorption technologies and obtained an energy requirement (at ideal conditions) that was similar to those recorded in this work.

In the in situ stripping process, the vacuum pump that facilitated the exit of purged $\mathrm{CO}_{2}$, as well as the purging mechanism itself, consumed a substantial amount of electricity. Other than that, beer distillation that was installed to recover the unstripped products in the retired fermentation broth used substantial amounts of energy due to the high volume of the fermentation broth. In addition to that, beer distillation only managed to moderately reduce the water content, resulting in moderately high energy requirement in the subsequent acetone, ethanol, and butanol distillation processes.

In the dual extraction process, the regeneration column, a series of the flash columns, as well as cooling and heating processes, have led to the high energy requirement of this process. The further product purification stage, however, required low energy because most of the water and extractants have been separated in the product separation stage.

In the adsorption process, the column heating required lower energy than those needed by the series of distillation in the product purification stage. In addition to that, the hydrophobic adsorbent only has selectivities towards acetone and butanol. There was no water removal stream from the adsorption column because the stream that escaped from the adsorbent contains ethanol, which eventually increased subsequent distillation work. Similarly, in the pervaporation process, stream heating in the product separation stage was a lot less than those required in the following distillation processes.

The total energy requirement for butanol production modeled using in situ stripping, adsorption, pervaporation, and dual extraction product separation technologies were $23.75 \mathrm{MJ} / \mathrm{L}, 30.11 \mathrm{MJ} / \mathrm{L}$, $19.43 \mathrm{MJ} / \mathrm{L}$, and $21.51 \mathrm{MJ} / \mathrm{L}$, respectively. Comparing only between product separation stages, those recording the lowest energy consumption were the adsorption technology. However, for the overall downstream section, the pervaporation process was the lowest energy method for ABE fermentation, followed by dual extraction, in situ stripping, and adsorption technologies with the energy requirement 
of 11.06 MJ/L, 13.08 MJ/L, 14.29 MJ/L, and 20.79 MJ/L, respectively. Dual extraction possesses high potential in further cost reduction by using more efficient extractants that could give better separation efficiencies. It is also worth highlighting that pervaporation technology possesses huge potential due to its low energy consumption and high product yields.

Available works from others recorded energy requirements in the range of 50-79 MJ/kg (41-64 MJ/L) for conventional distillation product purification in ABE fermentation process [13,61]. Energy requirements recorded by modern technologies assessed in this study were lower than those conventional methods. Nevertheless, considering the energy content of butanol $(\sim 28 \mathrm{MJ} / \mathrm{L})$, the adsorption model with the conditions evaluated in this study was regarded as an energy sink and, therefore, unfeasible for commercialization.

Figure 15 shows the comparison of utility cost requirement by application of partial CHP system (fueled by waste fibers only) and full CHP system (fueled by waste fibers and natural gas). The latter CHP system aimed to generate the steam needed for the processing and eliminate the need for outsourcing it. A substantial amount of electricity produced in the process used to power the plant and the excess portion was sold to the grid as income and counted as the by-product credit. Because adsorption technology required the highest amount of heat, it also generated the highest amount of excess electricity to be sold, and vice versa for the dual extraction model. Nevertheless, a high amount of electricity sold in the adsorption model was not able to compensate for the high CapEx and OpEx of this model.

(a)

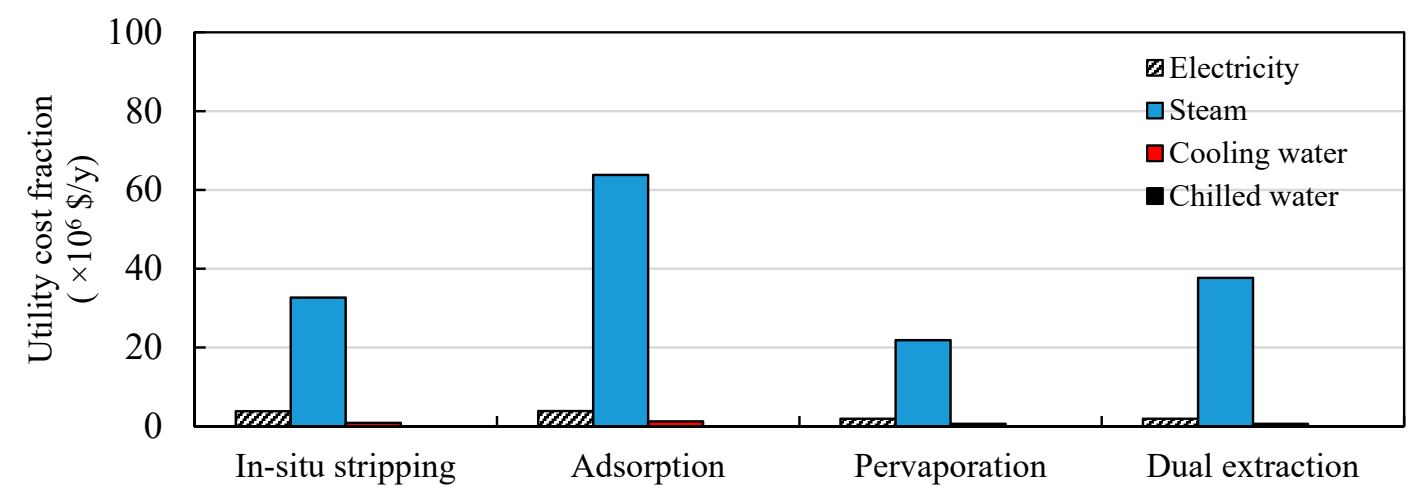

(b)

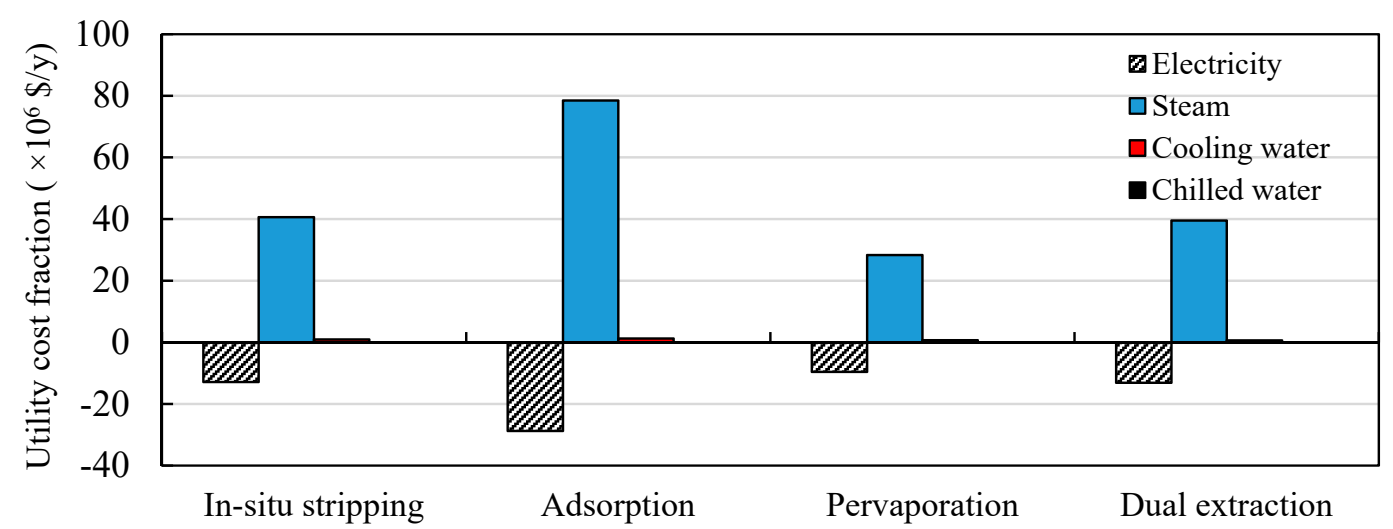

Figure 15. Utility cost fractions for butanol produced through ABE fermentation of LMAA-treated OPF simulated with different product separation technologies. (a) with partial CHP generation system, and (b) with full CHP generation system. 


\subsection{Production Costs Distributions}

Production cost distributions at each stage of the butanol production processes, modeled at different pretreatment and product separation technologies, are shown in Tables 4 and 5, respectively. The contributions of production cost at each stage of processing were from the materials/chemicals, consumables, natural gas used for heat and power generation, and water used for cooling purposes.

Table 4. Production cost distributions from different pretreatment models.

\begin{tabular}{ccccc}
\hline \multirow{2}{*}{ Production Stages } & \multicolumn{4}{c}{ Production Costs (\$/L) } \\
\cline { 2 - 4 } & LMAA & Autohydrolysis & SAA & NaOH \\
\hline Pretreatment & 0.16 & 1.98 & 3.77 & 0.61 \\
Enzyme Hydrolysis & 0.11 & 0.11 & 0.11 & 0.10 \\
Fermentation & 0.53 & 0.54 & 0.50 & 0.49 \\
Product Separation & 0.21 & 0.42 & 0.20 & 0.19 \\
Product Purification & 0.04 & 0.15 & 0.08 & 0.07 \\
CHP System & 0.06 & 0.31 & 0.09 & 0.06 \\
Other & 1.09 & 1.42 & 1.34 & 1.02 \\
By-Product Credit & 0.63 & 1.77 & 0.81 & 0.74 \\
Net cost & 1.58 & 3.15 & 5.28 & 1.79 \\
\hline
\end{tabular}

LMAA—low-moisture anhydrous ammonia; SAA—soaking in aqueous ammonia; $\mathrm{NaOH}-$ soaking in sodium hydroxide solution; $\mathrm{CHP}$ - combined heat and power.

Table 5. Production cost distributions from different product separation models.

\begin{tabular}{ccccc}
\hline \multirow{2}{*}{ Production Stages } & \multicolumn{4}{c}{ Production Costs $\mathbf{( \$ / \mathbf { L } )}$} \\
\cline { 2 - 5 } & In situ Stripping & Adsorption & Pervaporation & Dual Extraction \\
\hline Pretreatment & 0.16 & 0.15 & 0.15 & 0.15 \\
Enzyme Hydrolysis & 0.11 & 0.11 & 0.10 & 0.10 \\
Fermentation & 0.53 & 0.50 & 0.51 & 0.48 \\
Product Separation & 0.21 & 2.25 & 0.45 & 0.38 \\
Product Purification & 0.04 & 0.48 & 0.14 & 0.01 \\
CHP System & 0.06 & 0.09 & 0.04 & 0.05 \\
Other & 1.09 & 3.47 & 1.07 & 1.10 \\
By-Product Credit & 0.63 & 0.76 & 0.61 & 0.58 \\
Net cost & 1.58 & 6.29 & 1.86 & 1.70 \\
\hline
\end{tabular}

$\mathrm{CHP}$-combined heat and power.

Simulation of different pretreatment technologies resulted in varying pretreatment cost distributions between models. This condition was due to distinct efficiencies of each pretreatment, thus requiring a specific amount of feedstock to produce the same amount of cellulose for the subsequent process (hydrolysis). It was also due to the different processing conditions applied in each model. LMAA pretreatment was the cheapest pretreatment method with the cost of $\$ 0.16 / \mathrm{L}$, followed by $\mathrm{NaOH}$, autohydrolysis, and SAA pretreatments with values of $\$ 0.61 / \mathrm{L}, \$ 1.98 / \mathrm{L}$, and $\$ 3.77 / \mathrm{L}$, respectively. Some authors presented the pretreatment cost in combination with hydrolysis cost [15]. When applying this approach, the pretreatment costs were approximately $17 \%, 40 \%, 66 \%$, and $73 \%$ from the total butanol production costs for LMAA, $\mathrm{NaOH}$, autohydrolysis, and SAA models, respectively. The pretreatment costs obtained in this work were in the range of those recorded by Baral \& Shah [15]. Although the evaluated pretreatment technologies in their work were different from those assessed in this study, it suggests a baseline value on how much a pretreatment should cost.

Despite that, Adom et al. [2] mentioned that a pretreatment cost which takes more than $18 \%$ of the biofuel production cost as capital intensive. Considering this view, only the LMAA model possesses a potential for commercialization. Nevertheless, soaking in alkali pretreatment (SAA and $\mathrm{NaOH}$ ) could show a similar potential through improvement in processing conditions, i.e., running at a lower 
temperature and $\mathrm{S} / \mathrm{L}$ ratio than simulated in this work, or through reduction of pretreatment agents purchasing cost.

On the other hand, when different product separation technologies were simulated, considerable variation in production cost distribution was observed, starting from the product separation stage throughout the subsequent processes (see Table 5). The adsorption model recorded the highest separation cost followed by pervaporation, dual extraction, and in situ stripping with values of $\$ 2.25 / \mathrm{L}$, $\$ 0.45 / \mathrm{L}, \$ 0.38 / \mathrm{L}$, and $\$ 0.21 / \mathrm{L}$, respectively. These values are equivalent to $36 \%, 24 \%, 22 \%$, and $13 \%$ of the butanol production cost, for adsorption, pervaporation, dual extraction, and in situ stripping, respectively. As explained before, adsorption and pervaporation technologies did not remove any water in the product separation stage, which caused high energy consumption in the product purification stage. This situation was demonstrated by relatively high product purification costs in the adsorption and pervaporation models compared to the other two processes.

Among all product separation approaches modeled, adsorption technology required the highest energy (heat and power), which was shown by its high CHP cost as compared to the other models. Adsorption technology gave the highest by-product credit per liter of butanol produced. However, it could not compensate for the high CapEx and OpEx, which led to high butanol production cost. Among the lowest butanol production costs were recorded by in situ stripping and dual extraction model, which was due to different reasons. In the dual extraction model, the obtained butanol production cost was because of the low expenses of the product purification stage. In the in situ stripping model, the low butanol production cost was mainly on account of its low product separation cost and considerably high by-product credit.

\subsection{Uncertainties in the Simulated Models}

The presence of xylose gave the most substantial reduction in butanol production cost, except in the $\mathrm{NaOH}$ pretreatment model (see Figure 16). The cost reduction of around $26 \%, 13 \%, 19 \%$, and $21 \%$ were recorded for LMAA pretreatment/in situ stripping, $\mathrm{NaOH}$ pretreatment, pervaporation, and dual extraction models, respectively, when $20 \%$ xylose was assumed to be present in the treated OPF. Other important parameters affecting the butanol production costs were pretreatment and hydrolysis yields. In $\mathrm{NaOH}$ pretreatment model, the $20 \%$ higher pretreatment and hydrolysis yields recorded higher cost reduction than those mentioned above, with the value of $23 \%$ and $25 \%$ reduction from the baseline value, respectively. The prices of pretreatment agents, extractant, adsorbent, and land costs did not result in substantial effects on butanol production cost compared to the baseline value for all models.
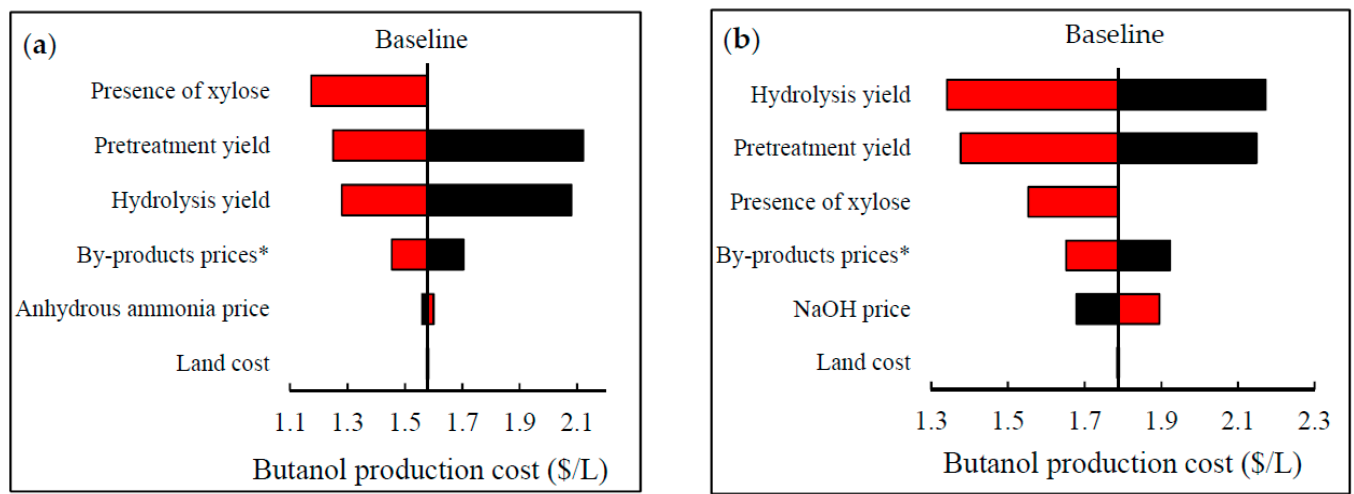

Figure 16. Cont. 

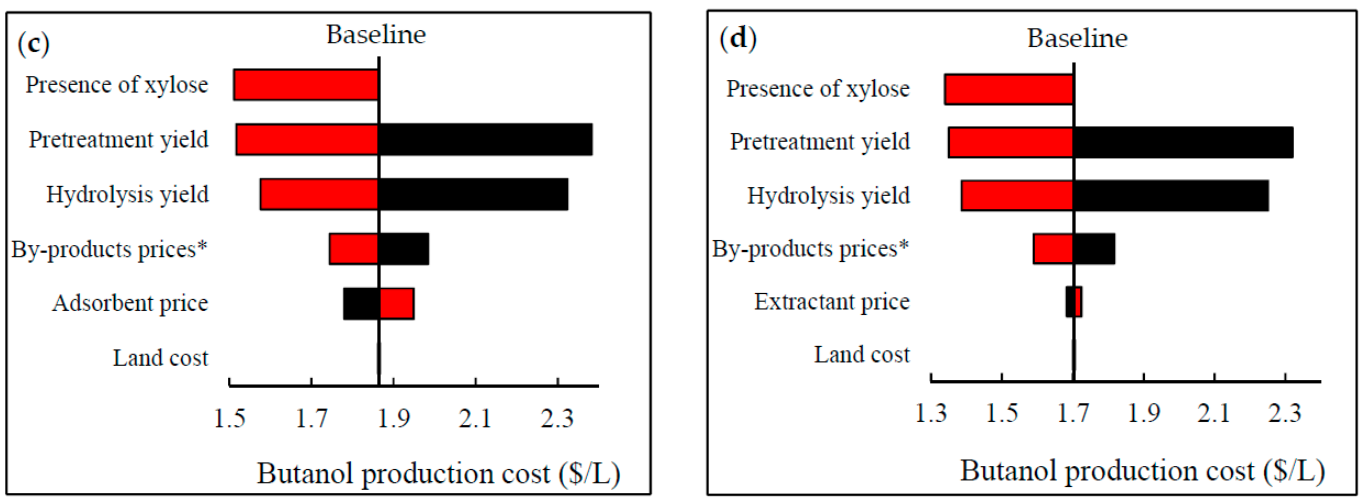

Figure 16. Sensitivity analysis of butanol production costs for different models. (a) LMAA pretreatment/in situ stripping; (b) $\mathrm{NaOH}$ pretreatment; (c) Pervaporation; (d) Dual extraction. Red-shaded bars are results of optimistic scenarios ( $+20 \%$ from the baseline); black-shaded bars are results of pessimistic scenarios $(-20 \%$ from the baseline).

Similarly, the presence of xylose resulted in the most substantial increase in the annual profit compared to those of other parameters (see Figure 17). However, the only profit recorded was from LMAA pretreatment/in situ stripping and dual extraction model in positive values, which were $\$ 29 \times 10^{6}$ and $\$ 9 \times 10^{6}$ annually, respectively. $\mathrm{NaOH}$ pretreatment model recorded positive profit of $\$ 7 \times 10^{6}$ and $\$ 3 \times 10^{6}$ annually when there was a $20 \%$ increase hydrolysis yield and pretreatment yield, respectively. The pervaporation model, on the other hand, did not record any positive profit at any case simulated due to the high OpEx from consumables. It seems that all simulated models produced a profit when the butanol production cost was lower than $\$ 1.40 / \mathrm{L}$.
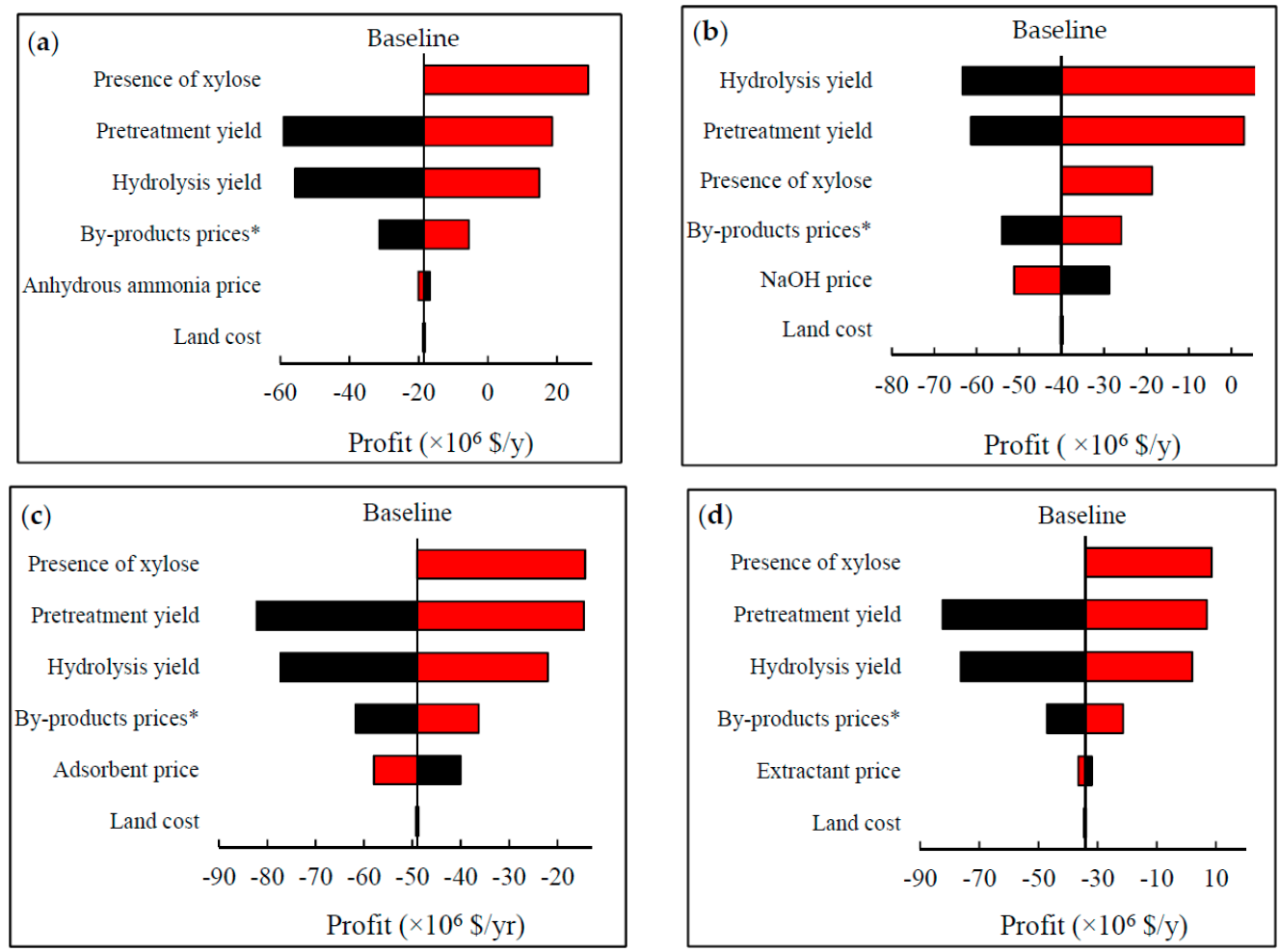

Figure 17. Sensitivity analysis of butanol production profits for different models. (a) LMAA pretreatment/in situ stripping; (b) $\mathrm{NaOH}$ pretreatment; (c) Pervaporation; (d) Dual extraction. Red-shaded bars are results of optimistic scenarios ( $+20 \%$ from the baseline); black-shaded bars are results of pessimistic scenarios (-20\% from the baseline). 


\subsection{Limitations and Future Scope for Research}

This study provided preliminary economic data on butanol production from OPF. The exclusion of xylose in the simulation was done due to lack of data on the amount of xylose after each pretreatment process. Sensitivity analysis showed that xylose content did contribute to considerable cost reduction. However, due to no available data, the sensitivity analysis failed to include important components such as the information of enzymes (i.e., type, concentration, reaction conditions, and reaction yield) used to catalyze the reaction. Therefore, more detail information on xylose conversion from hemicellulose could benefit the assessments and, therefore, should be the focus of future work.

Certain modeled processes were determined to have higher butanol production costs than the others, e.g., the adsorption process, which was determined to have high butanol production costs due to the high OpEx and energy requirement, and SAA pretreatment, which has high pretreatment agent costs. Attempts to reduce the production cost of these processes could not be conducted due to unknown relationships to the yield, i.e., simply reducing liquid ratio in SAA pretreatment or reducing the adsorbent regeneration temperature in the adsorption process will affect yields to an unknown degree. Other than that, future studies should also focus on cash flow analysis to give a better idea of the economic performance of butanol production from OPF.

\section{Conclusions}

In this study, the economic performance of cellulosic butanol production was analyzed using different pretreatment and product separation technologies. LMAA pretreatment, in combination with the in situ product separation approach, recorded the lowest butanol production cost (\$1.58/L). LMAA pretreatment has the benefit of the ability to recycle the pretreatment agent, which led to low material cost and waste treatment cost compared to the other pretreatment models. Even though the $\mathrm{NaOH}$ pretreatment model was capable of giving better product yields than the LMAA pretreatment, high material cost required by this process resulted in a higher butanol production cost $(\$ 1.79 / \mathrm{L})$. This study has validated the efficiency of LMAA pretreatment compared to the most similar pretreatment approach, SAA pretreatment, which used the same type of pretreatment agent. Energy consumption has been determined to be the most critical factor in giving the obtained result. Although the use of gaseous ammonia as the pretreatment agent and at lower feedstock moisture content did not notably affect the butanol production cost in LMAA pretreatment, elimination of high-temperature processing was able to substantially reduce the cost as compared to the other pretreatments modeled. When different product separation technologies were evaluated, following the butanol production cost that was given by in situ stripping technology was that from dual extraction approach $(\$ 1.70 / \mathrm{L})$. Energy and specific requirements of each model (i.e., adsorbent, extractant, and membrane) were the most critical factor, while product yields of each technology were the second factor affected by the butanol production cost. The LMAA pretreatment in situ stripping model recorded high profit when a $20 \%$ increase in value of several parameters was applied to the simulation, which was not the case for other models.

Author Contributions: N.M. conducted the modeling and wrote the original manuscript. K.A.R. directed the research and edited the manuscript. All authors have read and agreed to the published version of the manuscript.

Funding: This research received no external funding.

Conflicts of Interest: The authors declare no conflict of interest.

\section{References}

1. Abdi, H.K.; Alanazi, K.F.; Rohani, A.S.; Mehrani, P.; Thibault, J. Economic Comparison of a Continuous ABE Fermentation with and without the Integration of an in Situ Vacuum Separation Unit. Can. J. Chem. Eng. 2016, 94, 833-843. [CrossRef]

2. Adom, F.; Dunn, B.J.; Han, J. GREET Pretreatment Module; Argonne National Lab.: Argonne, IL, USA, 2014. 
3. Kurkijärvi, A.J.; Melin, K.; Lehtonen, J. Comparison of Reactive Distillation and Dual Extraction Processes for the Separation of Acetone, Butanol, and Ethanol from Fermentation Broth. Ind. Eng. Chem. Res. 2016, 55, 1952-1964. [CrossRef]

4. Outram, V.; Lalander, C.A.; Lee, J.G.M.; Davies, E.T.; Harvey, A.P. Applied in Situ Product Recovery in ABE Fermentation. Biotechnol. Prog. 2017, 33, 563-579. [CrossRef] [PubMed]

5. Karimi, K.; Tabatabaei, M.; Horváth, I.S.; Kumar, R. Recent Trends in Acetone, Butanol, and Ethanol (ABE) Production. Biofuel Res. J. 2015, 8, 301-308. [CrossRef]

6. Maiti, S.; Gallastegui, G.; Sarma, S.J.; Brar, S.K.; Le Bihan, Y.; Drogui, P.; Buelna, G.; Verma, M. A Re-Look at the Biochemical Strategies to Enhance Butanol Production. Biomass Bioenergy 2016, 94, 187-200. [CrossRef]

7. Friedl, A. Downstream Process Options for the ABE Fermentation. FEMS Microbiol. Lett. 2016, 363. [CrossRef]

8. Vane, L.M. Separation Technologies for the Recovery and Dehydration of Alcohols from Fermentation Broths. Biofuels Bioprod. Biorefin. 2008, 2, 553-588. [CrossRef]

9. Ezeji, T.C.; Qureshi, N.; Blaschek, H.P. Microbial Production of a Biofuel (Acetone-Butanol-Ethanol) in a Continuous Bioreactor: Impact of Bleed and Simultaneous Product Removal. Bioprocess Biosyst. Eng. 2013, 36, 109-116. [CrossRef]

10. Huang, H.J.; Ramaswamy, S.; Liu, Y. Separation and Purification of Biobutanol during Bioconversion of Biomass. Sep. Purif. Technol. 2014, 132, 513-540. [CrossRef]

11. Abdehagh, N.; Tezel, F.H.; Thibault, J. Separation Techniques in Butanol Production: Challenges and Developments. Biomass Bioenergy 2014, 60, 222-246. [CrossRef]

12. Ezeji, T.C.; Qureshi, N.; Blaschek, H.P. Butanol Fermentation Research: Upstream and Downstream Manipulations. Chem. Rec. 2004, 4, 305-314. [CrossRef] [PubMed]

13. Oudshoorn, A.; Van Der Wielen, L.A.M.; Straathof, A.J.J. Assessment of Options for Selective 1-Butanol Recovery from Aqueous Solution. Ind. Eng. Chem. Res. 2009, 48, 7325-7336. [CrossRef]

14. Sánchez-Ramírez, E.; Quiroz-Ramírez, J.J.; Segovia-Hernández, J.G.; Hernández, S.; Bonilla-Petriciolet, A. Process Alternatives for Biobutanol Purification: Design and Optimization. Ind. Eng. Chem. Res. 2015, 54, 351-358. [CrossRef]

15. Baral, N.R.; Shah, A. Comparative Techno-Economic Analysis of Steam Explosion, Dilute Sulfuric Acid, Ammonia Fiber Explosion and Biological Pretreatments of Corn Stover. Bioresour. Technol. 2017, 232, 331-343. [CrossRef] [PubMed]

16. Yoo, C.G.; Nghiem, N.P.; Hicks, K.B.; Kim, T.H. Pretreatment of Corn Stover Using Low-Moisture Anhydrous Ammonia (LMAA) Process. Bioresour. Technol. 2011, 102, 10028-10034. [CrossRef]

17. Nghiem, N.P.; Senske, G.E.; Kim, T.H. Pretreatment of Corn Stover by Low Moisture Anhydrous Ammonia (LMAA) in a Pilot-Scale Reactor and Bioconversion to Fuel Ethanol and Industrial Chemicals. Appl. Biochem. Biotechnol. 2016, 179, 111-125. [CrossRef]

18. Díaz, V.H.G.; Tost, G.O. Techno-Economic Analysis of Extraction-Based Separation Systems for Acetone, Butanol, and Ethanol Recovery and Purification. Bioresour. Bioprocess. 2017, 4. [CrossRef]

19. Qureshi, N.; Hughes, S.; Maddox, I.S.; Cotta, M.A. Energy-Efficient Recovery of Butanol from Model Solutions and Fermentation Broth by Adsorption. Bioprocess Biosyst. Eng. 2005, 27, 215-222. [CrossRef]

20. Abdehagh, N.; Tezel, F.H.; Thibault, J. Adsorbent Screening for Biobutanol Separation by Adsorption: Kinetics, Isotherms and Competitive Effect of Other Compounds. Adsorption 2013, 19, 1263-1272. [CrossRef]

21. Abdehagh, N.; Gurnani, P.; Tezel, F.H.; Thibault, J. Adsorptive Separation and Recovery of Biobutanol from ABE Model Solutions. Adsorption 2015, 21, 185-194. [CrossRef]

22. Van Hecke, W.; Hofmann, T.; De Wever, H. Pervaporative Recovery of ABE during Continuous Cultivation: Enhancement of Performance. Bioresour. Technol. 2013, 129, 421-429. [CrossRef] [PubMed]

23. Chen, C.; Xiao, Z.; Tang, X.; Cui, H.; Zhang, J.; Li, W.; Ying, C. Acetone-Butanol-Ethanol Fermentation in a Continuous and Closed-Circulating Fermentation System with PDMS Membrane Bioreactor. Bioresour. Technol. 2013, 128, 246-251. [CrossRef] [PubMed]

24. Van Hecke, W.; Vandezande, P.; Claes, S.; Vangeel, S.; Beckers, H.; Diels, L.; De Wever, H. Integrated Bioprocess for Long-Term Continuous Cultivation of Clostridium Acetobutylicum Coupled to Pervaporation with PDMS Composite Membranes. Bioresour. Technol. 2012, 111, 368-377. [CrossRef] [PubMed]

25. Negishi, H.; Sakaki, K.; Ikegami, T. Silicalite Pervaporation Membrane Exhibiting a Separation Factor of over 400 for Butanol. Chem. Lett. 2010, 39, 1312-1314. [CrossRef] 
26. Qureshi, N.; Blaschek, H.P. Production of Acetone Butanol Ethanol (ABE) by a Hyper-Producing Mutant Strain of Clostridium Beijerinckii BA101 and Recovery by Pervaporation. Biotechnol. Prog. 1999, 15, 594-602. [CrossRef]

27. de Vrije, T.; Budde, M.; van der Wal, H.; Claassen, P.A.M.; López-Contreras, A.M. In Situ Removal of Isopropanol, Butanol and Ethanol from Fermentation Broth by Gas Stripping. Bioresour. Technol. 2013, 137, 153-159. [CrossRef]

28. Xue, C.; Zhao, J.; Liu, F.; Lu, C.; Yang, S.T.; Bai, F.W. Two-Stage in Situ Gas Stripping for Enhanced Butanol Fermentation and Energy-Saving Product Recovery. Bioresour. Technol. 2013, 135, 396-402. [CrossRef]

29. Department of Agriculture Malaysia. Industrial Crops Statistics; Department of Agriculture Malaysia: Putrajaya, Malaysia, 2016.

30. Cheng, M.; Rosentrater, K.A. Optimization of Low Moisture Anhydrous Ammonia (LMAA) Pretreatment for Corn Stover Enzymatic Digestibility during Hydrolysis Process. In Proceedings of the 2016 ASABE Annual International Meeting, Orlando, FL, USA, 17-20 July 2016. [CrossRef]

31. Yang, M.; Rosentrater, K.A. Small-Scale Low-Moisture Anhydrous Ammonia (LMAA) Pretreatment of Corn Stover. Biomass Bioenergy 2017, 97, 38-42. [CrossRef]

32. Mahmud, N. Low Moisture Anhydrous Ammonia (LMAA) Pretreatment of Lignocellulosic Biomass and Assessments for Biobutanol Production. Ph.D. Thesis, Iowa State University, Ames, IA, USA, 2019.

33. Sabiha-Hanim, S.; Noor, M.A.M.; Rosma, A. Effect of Autohydrolysis and Enzymatic Treatment on Oil Palm (Elaeis Guineensis Jacq.) Frond Fibres for Xylose and Xylooligosaccharides Production. Bioresour. Technol. 2011, 102, 1234-1239. [CrossRef]

34. Jung, Y.H.; Kim, S.; Yang, T.H.; Lee, H.J.; Seung, D.; Park, Y.-C.; Seo, J.-H.; Choi, I.-G.; Kim, K.H. Aqueous Ammonia Pretreatment, Saccharification, and Fermentation Evaluation of Oil Palm Fronds for Ethanol Production. Bioprocess Biosyst. Eng. 2012, 35, 1497-1503. [CrossRef]

35. Sukri, S.S.M.; Rahman, R.A.; Illias, R.M.D.; Yaakob, H. Optimization of Alkaline Pretreatment Conditions of Oil Palm Fronds in Improving the Lignocelluloses Contents for Reducing Sugar Production. Rom. Biotechnol. Lett. 2014, 19, 9006-9018. [CrossRef]

36. Triwahyuni, E.; Hariyanti, S.; Dahnum, D.; Nurdin, M.; Abimanyu, H. Optimization of Saccharification and Fermentation Process in Bioethanol Production from Oil Palm Fronds. Procedia Chem. 2015, 16, 141-148. [CrossRef]

37. Ezeji, T.C.; Blaschek, H.P. Fermentation of Dried Distillers' Grains and Solubles (DDGS) Hydrolysates to Solvents and Value-Added Products by Solventogenic Clostridia. Bioresour. Technol. 2008, 99, 5232-5242. [CrossRef] [PubMed]

38. Tao, L.; He, X.; Tan, E.C.D.; Zhang, M.; Aden, A. Comparative Techno-Economic Analysis and Reviews of n-Butanol Production from Corn Grain and Corn Stover. Biofuels Bioprod. Biorefin. 2014, 8, 342-361. [CrossRef]

39. Qureshi, N.; Ezeji, T.C.; Ebener, J.; Dien, B.S.; Cotta, M.A.; Blaschek, H.P. Butanol Production by Clostridium Beijerinckii. Part I: Use of Acid and Enzyme Hydrolyzed Corn Fiber. Bioresour. Technol. 2008, 99, 5915-5922. [CrossRef] [PubMed]

40. Wu, M.; Wang, M.; Liu, J.; Huo, H. Assessment of Potential Life-Cycle Energy and Greenhouse Gas Emission Effects from Using Corn-Based Butanol as a Transportation Fuel. Biotechnol. Prog. 2008, 24, 1204-1214. [CrossRef]

41. Baral, N.R.; Shah, A. Techno-Economic Analysis of Cellulosic Butanol Production from Corn Stover through Acetone-Butanol-Ethanol Fermentation. Energy Fuels 2016, 30, 5779-5790. [CrossRef]

42. Ezeji, T.C.; Qureshi, N.; Blaschek, H.P. Production of Acetone, Butanol and Ethanol by Clostridium Beijerinckii BA101 and in Situ Recovery by Gas Stripping. World J. Microbiol. Biotechnol. 2003, 19, 595-603. [CrossRef]

43. Águeda, V.I.; Delgado, J.A.; Uguina, M.A.; Sotelo, J.L.; García, Á. Column Dynamics of an Adsorption-Drying-Desorption Process for Butanol Recovery from Aqueous Solutions with Silicalite Pellets. Sep. Purif. Technol. 2013, 104, 307-321. [CrossRef]

44. Hussin, M.H.; Samad, N.A.; Latif, N.H.A.; Rozuli, N.A.; Yusoff, S.B.; Gambier, F.; Brosse, N. Production of Oil Palm (Elaeis Guineensis) Fronds Lignin-Derived Non-Toxic Aldehyde for Eco-Friendly Wood Adhesive. Int. J. Biol. Macromol. 2018, 113, 1266-1272. [CrossRef]

45. Demirbaş, A. Estimating of Structural Composition of Wood and Non-Wood Biomass Samples. Energy Sources 2005, 27, 761-767. [CrossRef] 
46. Morvay, Z.K.; Gvozdenac, D.D. Applied Industrial Eenergy and Environmental Management; John Wiley \& Sons: Hoboken, NJ, USA, 2008.

47. Haigh, K.F.; Petersen, A.M.; Gottumukkala, L.; Mandegari, M.; Naleli, K.; Görgens, J.F. Simulation and Comparison of Processes for Biobutanol Production from Lignocellulose via ABE Fermentation. Biofuels Bioprod. Biorefin. 2018, 12, 1023-1036. [CrossRef]

48. Richardson. Richardson International Construction Factors Manual ${ }^{T M}$; Cost Data On Line, Inc.: Pahrump, NV, USA, 2008.

49. Heinzle, E.; Biwer, A.P.; Cooney, C.L. Development of Sustainable Bioprocesses: Modelling and Assessment; John Wiley \& Sons: Hoboken, NJ, USA, 2006.

50. Brown, R.C.; Brown, T.R. Economics of Biorenewable Resources. In Biorenewable Resources: Engineering New Products from Agriculture, 2nd ed.; John Wiley \& Sons, Inc.: Hoboken, NJ, USA, 2014; pp. 287-326.

51. Utusan-Malaysia. Kilang Pelet Pelepah Sawit Untuk Ternakan. Available online: http://integratedfarm. blogspot.com/2009/07/kilang-pelet-pelepah-sawit-untuk.html (accessed on 8 September 2016).

52. Schnitkey, G. Weekly Farm Economics: Fertilizer Prices Higher for 2019 Crop. Farmdoc Dly. 2018, 8, 178.

53. You, Z.; Zhang, S.; Kim, H.; Chiang, P.-C.; Sun, Y.; Guo, Z.; Xu, H. Effects of Corn Stover Pretreated with $\mathrm{NaOH}$ and $\mathrm{CaO}$ on Anaerobic Co-Digestion of Swine Manure and Corn Stover. Appl. Sci. 2019, 9, 123. [CrossRef]

54. Wang, Y.; Liu, Z.; Hao, P. Investigation on Mechanical and Microwave Heating Characteristics of Asphalt Mastic Using Activated Carbon Powder as Electro-Magnetic Absorbing Materials. Constr. Build. Mater. 2019, 202, 692-703. [CrossRef]

55. TNB-Malaysia. Pricing \& Tariffs. Available online: http://www.tnb.com.my/residential/pricing-tariffs (accessed on 10 March 2018).

56. SPAN-Malaysia. Water Tariff. Available online: https://www.span.gov.my/document/upload/ AtBz79IrBNcxpXRh9R2SXYAcr1cAZ5oK.pdf (accessed on 10 March 2018).

57. UHY. Doing Business in Malaysia; Urbach Hacker Young International Ltd.: Kuala Lumpur, Malaysia, 2015. [CrossRef]

58. Richard, R. Kenyataan Media: Perintah Gaji Minimum 2016; Ministry of Human Resources Malaysia: Putrajaya, Malaysia, 2016.

59. Mahmud, N.; Rosentrater, K.A. Techno-Economic Analysis of Low Moisture Anhydrous Ammonia (LMAA) Pretreatment for Butanol Production from Oil Palm Frond. Biomass Convers. Biorefin. 2019. [CrossRef]

60. Yang, M.; Rosentrater, K.A. Techno-Economic Analysis (TEA) of Low-Moisture Anhydrous Ammonia (LMAA) Pretreatment Method for Corn Stover. Ind. Crops Prod. 2015, 76, 55-61. [CrossRef]

61. Matsumura, M.; Kataoka, H.; Sueki, M.; Araki, K. Energy Saving Effect of Pervaporation Using Oleyl Alcohol Liquid Membrane in Butanol Purification. Bioprocess Eng. 1988, 3, 93-100. [CrossRef] 